\title{
A Study of the Antibacterial Activities and the Mode of Action of L-Methionine and L-Cystine Based Surfactants and their Interaction with Bovine Serum Albumin Using Fluorescence Spectroscopy and in Silico Modelling
}

\author{
Sabina Jhaumeer Laulloo ${ }^{1,2}$ (D), Prakashanand Caumul ${ }^{1,2}$ (D), Nausheen Joondan ${ }^{1,2}$, \\ Shobha Jawaheer ${ }^{2,3}$ (D), Sundev Parboteeah ${ }^{2,3}$ (D), Sabrina Devi Dyall ${ }^{2,3}$ (D), Minu Gupta Bhowon $1,2, *$ (D) \\ 1 Department of Chemistry, Faculty of Science, University of Mauritius, Réduit 80837, Republic of Mauritius \\ 2 Molecular Life Sciences Pole of Research Excellence, Faculty of Science, University of Mauritius, Réduit 80837, Republic \\ of Mauritius \\ 3 Department of Biosciences and Ocean Studies, Faculty of Science, University of Mauritius, Réduit 80837, Republic of \\ Mauritius \\ * Correspondence: mbhowon@uom.ac.mu (M.G.B);
}

Scopus Author ID 6603531359

Received: 1.10.2021; Revised: 5.11.2021; Accepted: 8.11.2021; Published: 24.11.2021

\begin{abstract}
Surfactants are versatile excipients that are commonly employed in diverse pharmaceutical formulations given their broad range of antimicrobial activities. Sulfur-based amino acid surfactants are promising candidates as substitutes for conventional antibacterial agents in light of the current antibiotic resistance crisis. Dodecyl esters of the free amine (SURF1), cationic ester hydrochloride (SURF2), and quaternary ammonium (QUAT3) derivatives of methionine, and the Gemini diester of cystine (GEM4) were synthesized and evaluated for antibacterial activity against Gram-positive and Gram-negative pathogens. All surfactants displayed moderate to high antibacterial activities, particularly on Grampositive bacteria, with QUAT3 showing the highest activity. Among Gram-negative bacteria, QUAT3, GEM4, and SURF2 were mostly active towards $K$. pneumoniae with minimum inhibitory concentrations (MIC) ranging from 0.004 to $0.441 \mathrm{mM}$. QUAT3 and GEM4 displayed a bacteriostatic behavior similar to that of tetracycline, as assessed by broth macrodilution assays. Fluorescence binding studies with 1,2-dipalmitoyl-sn-glycero-3-phosphocholine (DPPC) revealed that the antibacterial activities could be attributed to a combination of electrostatic and hydrophobic interactions. Bovine serum albumin (BSA) fluorescence and molecular docking studies indicated that SURF1 and QUAT3 interact mainly via van der Waals' forces and hydrogen bonding while SURF2 binds through hydrophobic interactions. QUAT3, which displays broad-spectrum activity, has the potential to combat drug-resistant bacteria.
\end{abstract}

Keywords: surfactant; methionine; cystine; antibacterial activity; phospholipid binding; bovine serum albumin; molecular docking

(C) 2021 by the authors. This article is an open-access article distributed under the terms and conditions of the Creative Commons Attribution (CC BY) license (https://creativecommons.org/licenses/by/4.0/).

\section{Introduction}

The increase in the prevalence of antibiotic-resistant microorganisms, together with a lack of newly developed antimicrobial drugs, is bringing a great threat to the community in dealing with multidrug-resistant bacterial infections [1]. Thus, the design and development of new compounds with a wide range of antimicrobial activities impede the development of acquired resistance is essential to combat infectious diseases. 
Surfactants continue to attract the interest of researchers because of their wide range of applications in the pharmaceutical, medical, cosmetic, and detergent industries. They are known to exhibit a broad spectrum of antimicrobial properties [2,3] through various mechanisms, including direct interaction with bacterial cell membranes, leading to cell lysis and eventually bacterial cell death [4,5]. Hence, surfactants show less susceptibility to antimicrobial resistance and have been suggested as future therapeutics against drug-resistant bacteria [6].

Conventional petroleum-based surfactants have adverse effects on the environment. Therefore, amino acid-based surfactants have emerged as a promising biocompatible and biodegradable class of compounds for biomedical application due to their improved safety profile in terms of physiological and ecological compatibility [7,8]. Head group architecture influences the antimicrobial activity of the surfactants, as the type and charges dictate the interaction with the bacterial cell membrane $[9,10]$. The molecular design of these surfactants, which results in different modes of antibacterial action, could make them potent alternatives to existing antibiotics in curtailing antibiotic resistance.

Many non-ionic, cationic, and anionic amino acid surfactants from different amino acids have been explored for their antimicrobial properties. An increase in the hydrophobic character of the surfactants is known to improve their antibacterial activity. Several studies have shown that increasing alkyl chain length leads to enhanced activity with a cut-off at $\mathrm{C}_{12}$ $[11,12]$. Additionally, Gemini surfactants show diverse properties compared to monomeric surfactants, such as lower critical micelle concentration and better antimicrobial properties due to the presence of a double chain system that provides additional hydrophobic contacts [13]. Recently, our group and other researchers reported the synthesis of surfactants derived from sulfur-based amino acids [14-16]. Methionine and cystine are considered non-polar and hydrophobic amino acids, consisting of a potentially reactive sulfur group capable of enhancing the biological properties of their derivatives[17]. Yoshimura et al. (2007) reported that monomeric and dimeric $N$-alkylamine surfactants derived from cysteine with higher chain length had a greater tendency to form small uni-lamellar vesicles than micelles [18]. Ureabased Gemini surfactants derived from cystine have been reported to show lower critical micelle concentration (CMC) than their monomeric counterpart, whereas the monomeric surfactants derived from cystine and methionine showed a greater ability to lower surface tension [15]. Perinelli et al.(2019) reported that quaternary ammonium surfactants derived from the amino acid methionine, bearing $\mathrm{C}_{12}$ and $\mathrm{C}_{14}$ alkyl chains, showed comparable antimicrobial activities to benzalkonium chloride, a known biocidal compound [19].

In the present work, our aim was to develop sulfur-based amino acid surfactants with antibacterial activities. With this view, we have synthesized a $\mathrm{C}_{12}$ Gemini surfactant derived from cystine and compared its properties with monomeric surfactants derived from methionine. The surfactants were evaluated for antibacterial potential against Gram-positive and Gramnegative strains. Investigation of their mode of action with phospholipids as model membranes together with the study of their interactions with bovine serum albumin (BSA) using fluorescence spectroscopy and molecular docking studies were undertaken to provide more insight into their potential applicability as therapeutic agents. 


\section{Materials and Methods}

\subsection{Chemicals.}

L-Methionine, cetyl trimethyl ammonium bromide (CTAB), and iodomethane were purchased from BDH Laboratory Supplies (England). L-Cystine, 1-dodecanol, 1-anilino-8naphthalene sulfonate (ammonium salt; ANS), 1,6-diphenyl-1,3,5-hexatriene (DPH), and Trisbuffered saline (0.05 M, pH 7.4) were obtained from Sigma-Aldrich. 1,2- Dipalmitoyl-snglycero-3-phosphocholine (DPPC) was obtained from Avanti Polarlipids, Inc. Mueller Hinton agar, and broths were purchased from Oxoid Ltd (United Kingdom). The different bacterial strains were obtained from Microbiologics ${ }^{\circledR}$ (St Cloud, MN, USA) and Oxoid Ltd (United Kingdom).

\subsection{Instrumentation.}

${ }^{1} \mathrm{H}$ and ${ }^{13} \mathrm{C}$ NMR spectra were recorded at 250 and $62.9 \mathrm{MHz}$ on a Bruker electro spin NMR spectrometer using $\mathrm{CDCl}_{3}$ as solvent. IR spectra were recorded on a Bruker Alpha FTIR spectrophotometer. Conductivity measurements were recorded using a Jenway 4510 conductivity meter. Sonification was carried out using a Soniprep 150 sonifier. Fluorescence intensities were recorded on an LS 55 Perkin Elmer fluorescence spectrophotometer.

\subsection{Synthesis of L-methionine-based surfactants.}

The methionine-based surfactants SURF1, SURF2, and QUAT3 were synthesized using the modified reported procedure [19].

\subsubsection{Methionine dodecyl ester, SURF1.}

Methionine (1.8 g, $12.1 \mathrm{mmol})$, dodecanol (3.3 ml, $14.5 \mathrm{mmol})$ and PTSA (4.6 g, 24.2) were refluxed in toluene for $48 \mathrm{~h}$. The crude oil obtained was then purified by column chromatography on silica gel with EtOAc/Hexane (1:2) to obtain the compound as an oil. Yield: $56.6 \%$. IR v/cm ${ }^{-1}: 2920 \& 2853(\mathrm{C}-\mathrm{H}), 1733(\mathrm{C}=\mathrm{O}), 1241(\mathrm{C}-\mathrm{N}), 1177(\mathrm{C}-\mathrm{O}), 722$ (SC). ${ }^{1} \mathrm{H}-\mathrm{NMR}\left(\mathrm{CDCl}_{3}\right) \delta(\mathrm{ppm}): 0.75-0.79\left(\mathrm{t}, 3 \mathrm{H}, \mathrm{CH}_{3}, \mathrm{~J}=6.3 \mathrm{~Hz}\right), 1.16\left(\mathrm{~m}, 18 \mathrm{H},\left(\mathrm{CH}_{2}\right)_{9}\right), 1.55$ (m, 2H, CH 2 ), 1.69-1.96 (m, 2H, $\left.\mathrm{CH}_{2}\right), 2.01\left(\mathrm{~s}, 3 \mathrm{H}, \mathrm{SCH}_{3}\right), 2.49-2.55\left(\mathrm{t}, 2 \mathrm{H}, \mathrm{CH}_{2} \mathrm{~S}, \mathrm{~J}=7.4\right.$ $\mathrm{Hz}), 3.45-3.50(\mathrm{~m}, 1 \mathrm{H}, \mathrm{CHC}=\mathrm{O}), 3.98-4.04\left(\mathrm{t}, 2 \mathrm{H},-\mathrm{OCH}_{2} \mathrm{CH}_{2}, \mathrm{~J}=6.7 \mathrm{~Hz}\right) .{ }^{13} \mathrm{C}-\mathrm{NMR}\left(\mathrm{CDCl}_{3}\right)$ $\delta$ (ppm): 14.1, 15.3, 22.7-25.9, 28.6, 29.2, 29.6, 30.5, 31.9, 34.0, 53.3, 65.2, $175.8(\mathrm{C}=\mathrm{O})$.

\subsubsection{Methionine dodecyl ester hydrochloride, SURF2.}

The ester hydrochloride derivative was obtained by bubbling $\mathrm{HCl}$ gas through the free amine derivative SURF1. Yield: $40.8 \%$. IR $v / \mathrm{cm}^{-1}: 2850 \& 2918(\mathrm{C}-\mathrm{H}), 1737(\mathrm{C}=\mathrm{O}), 1598.87$ $(\mathrm{N}-\mathrm{H}), 1482\left(\mathrm{CH}_{2}\right), 1285(\mathrm{C}-\mathrm{N}), 1210(\mathrm{C}-\mathrm{O}), 722\left(\mathrm{~S}_{-} \mathrm{CH}_{3}\right) .{ }^{1} \mathrm{H}-\mathrm{NMR}\left(\mathrm{CDCl}_{3}\right) \delta(\mathrm{ppm}): 0.86-$ $0.88\left(\mathrm{t}, 3 \mathrm{H}, \mathrm{CH}_{3}, \mathrm{~J}=7 \mathrm{~Hz}\right), 1.24\left(\mathrm{~m}, 18 \mathrm{H},\left(\mathrm{CH}_{2}\right)_{9}\right), 1.62-1.67\left(\mathrm{~m}, 2 \mathrm{H}, \mathrm{CH}_{2}\right), 2.11\left(\mathrm{~s}, 3 \mathrm{H}, \mathrm{SCH}_{3}\right)$, 2.24-2.34 (m, 2H, $\left.\mathrm{CH}_{2}\right), 2.69-2.75\left(\mathrm{~m}, 2 \mathrm{H}, \mathrm{CH}_{2} \mathrm{~S}\right), 4.00\left(\mathrm{~m}, 1 \mathrm{H}, \mathrm{CH}\left(\mathrm{N}^{+} \mathrm{H}_{3}\right)\right), 4.17-4.24(\mathrm{~m}, 2 \mathrm{H}$, $\left.\mathrm{OCH}_{2}\right) .{ }^{13} \mathrm{C}-\mathrm{NMR}\left(\mathrm{CDCl}_{3}\right) \delta(\mathrm{ppm}): 14.1,15.1,22.7-29.6,29.7,31.9,52.1,67.0,169.6(\mathrm{C}=\mathrm{O})$.

\subsubsection{Methionine dodecyl quaternary ammonium ester chloride, QUAT3.}

L-Methionine dodecyl ester $(0.5 \mathrm{~g}, 1.6 \mathrm{mmol})$ and anhydrous potassium carbonate $(1.2$ $\mathrm{g}, 8.8 \mathrm{mmol})$ were dissolved in acetonitrile $(10 \mathrm{ml})$ and an excess of methyl iodide $(2.0 \mathrm{ml}$, 
$32.1 \mathrm{mmol}$ ) was added. The reaction mixture was stirred at ambient temperature for 24 hours. The mixture was filtered and the solvent removed under vacuo. A white solid was obtained and it was washed with $\mathrm{Et}_{2} \mathrm{O}(25 \mathrm{ml})$ to obtain the pure solid. Yield: $66 \%$. IR v/cm $\mathrm{cm}^{-1}: 2922 \& 2853$ (C-H), 1735 (C=O, 1244 (C-N), 1163 (C-O), 720 (S-C). ${ }^{1} \mathrm{H}-\mathrm{NMR}\left(\mathrm{CDCl}_{3}\right) \delta$ (ppm): 0.79-0.84 (t, 3H, CH $3, \mathrm{~J}=6.5 \mathrm{~Hz}), 1.20$ (s, 18H, $\left.\left(\mathrm{CH}_{2}\right)_{9}\right), 1.48-1.53$ (m, 2H, $\left.\mathrm{CH}_{2}, \mathrm{~J}=6.5 \mathrm{~Hz}\right), 2.19$ (s, 3H, $\left.\mathrm{SCH}_{3}\right), 2.27-2.24\left(\mathrm{~m}, 2 \mathrm{H}, \mathrm{CH}_{2}\right), 2.53-2.55\left(\mathrm{~m}, 2 \mathrm{H}, \mathrm{CH}_{2} \mathrm{~S}, \mathrm{~J}=6.6 \mathrm{~Hz}\right), 3.55\left(\mathrm{~s}, 9 \mathrm{H},{ }^{+} \mathrm{N}\left(\mathrm{CH}_{3}\right)_{3}\right)$, 4.05-4.10 (t, 2H, $\left.-\mathrm{OCH}_{2}, \mathrm{~J}=6.6 \mathrm{~Hz}\right), 4.18-4.23(\mathrm{t}, 1 \mathrm{H},-\mathrm{CH}=\mathrm{O}, \mathrm{J}=6.5 \mathrm{~Hz}) .{ }^{13} \mathrm{C}-\mathrm{NMR}\left(\mathrm{CDCl}_{3}\right)$, $\delta$ (ppm): 9.4, 17.9, 21.0, 24.6-24.9, 27.2, 28.1, $48.4\left({ }^{+} \mathrm{N}\left(\mathrm{CH}_{3}\right)_{3}\right), 58.3\left(\mathrm{OCH}_{2}\right), 162.3(\mathrm{C}=\mathrm{O})$.

\subsection{Synthesis of L-cystine-based surfactant, L-Cystine didodecyl ester, GEM4.}

L-Cystine (1.9 g, $8.3 \mathrm{mmol})$, PTSA (6.3 g, $33.6 \mathrm{mmol})$ and 1-dodecanol (3.3 ml, 14.8 $\mathrm{mmol})$ in toluene $(100 \mathrm{ml})$ was refluxed for 48 hours in a Dean-Stark apparatus. The excess organic solvent was removed and the $p$-toluene sulfonate salt of the ester was washed with excess diethyl ether. The resulting solid was dissolved in $2 \mathrm{M} \mathrm{NaOH}(100 \mathrm{ml})$ and extracted with EtOAc $(100 \mathrm{ml})$ to afford the product as an oil. Yield: $74 \mathrm{IR} v / \mathrm{cm}^{-1}: 3368(\mathrm{~N}-\mathrm{H}), 2921 \&$ $2852(\mathrm{C}-\mathrm{H}), 1736(\mathrm{C}=\mathrm{O}) 1258(\mathrm{C}-\mathrm{N}), 1173(\mathrm{C}-\mathrm{O}), 721(\mathrm{~S}-\mathrm{C}) .{ }^{1} \mathrm{H} \mathrm{NMR}\left(\mathrm{CDCl}_{3}\right) \delta(\mathrm{ppm}): 0.77-$ $0.82\left(\mathrm{t}, 6 \mathrm{H}, 2 \times \mathrm{CH}_{3}, \mathrm{~J}=6.5 \mathrm{~Hz}\right), 1.18-1.22\left(\mathrm{~m}, 36 \mathrm{H}, 2 \times\left(\mathrm{CH}_{2}\right)_{9}\right), 1.54-1.62\left(\mathrm{~m}, 4 \mathrm{H}, 2 \times \mathrm{CH}_{2}\right)$, 2.06 (s, 4H, NH 2 ), 2.79-3.09 (4H, dd, $\left.2 \mathrm{xCH}_{2}-\mathrm{S}, \mathrm{J}=7.7,4.5 \mathrm{~Hz}\right), 3.69-3.82\left(\mathrm{~m}, 2 \mathrm{H}, \mathrm{CH}_{2}\right), 4.03-$ $4.08\left(\mathrm{t}, 4 \mathrm{H}, 2 \times \mathrm{OCH}_{2}, \mathrm{~J}=6.8 \mathrm{~Hz}\right) .{ }^{13} \mathrm{C}-\mathrm{NMR}\left(\mathrm{CDCl}_{3}\right), \delta(\mathrm{ppm}): 14.1,22.7,25.8-25.9,28.5$, 29.2-29.6, 31.9, 43.6, 53.6, 65.6, $173.7(\mathrm{C}=\mathrm{O})$.

\subsection{Determination of critical micellar concentration $(C M C)$.}

The critical micelle concentration (CMC) of SURF2 and QUAT3 were determined in an aqueous solution at $25^{\circ} \mathrm{C}$ using conductivity, while the CMC of SURF1 and GEM4 were determined using pyrene fluorescence measurements at $25^{\circ} \mathrm{C}$ [20].

\subsection{Antibacterial susceptibility testing.}

Antimicrobial activities were determined against six test organisms: three Grampositive bacteria, namely Staphylococcus aureus (ATCC 29213), Bacillus cereus (ATCC 11778) and Staphylococcus epidermidis (ATCC 12228), and three Gram-negative bacteria, namely Escherichia coli (ATCC 25922), Klebsiella pneumoniae (ATCC 13883) and Pseudomonas aeruginosae (ATCC 27853), using the broth micro- and macro-dilution methods. The strains were cultured in sterile Mueller Hinton broth for 18 hours at $37^{\circ} \mathrm{C}$.

\subsection{Broth microdilution.}

Overnight cultures of the test pathogens were diluted to the turbidity of $A_{600}=0.2$. Sterile Mueller-Hinton broth $(50 \mu \mathrm{l})$ with varying concentrations of the surfactants to be tested was added to the diluted test cultures $(50 \mu \mathrm{l})$ in 96 -well plates. The plates were incubated for $24 \mathrm{hrs}$ at $37^{\circ} \mathrm{C}$. After incubation, the $\mathrm{A}_{600}$ was recorded on a microplate reader (Synergy ${ }^{\mathrm{TM}} \mathrm{HT}$ MultiMode Microplate Reader), and the MIC of each surfactant was determined by the addition of iodonitrotetrazolium chloride $(20 \mu \mathrm{l}, 0.4 \mathrm{mg} / \mathrm{ml})$ followed by further incubation at $37^{\circ} \mathrm{C}$ for 30 min. Viable microorganisms reduced the yellow dye to pink color. DMSO and tetracycline (10 $\mu \mathrm{g} / \mathrm{ml}$ ) were used as negative and positive controls, respectively.

\subsection{Broth macrodilution.}


Viability curves of Klebsiella pneumonia and Bacillus cereus were followed for QUAT3 and GEM4. Sterile Mueller Hinton broth $(50 \mathrm{ml})$ was inoculated with selected test bacteria cultures $(50 \mu \mathrm{l})$ and shaken at $220 \mathrm{rpm}$ at $37^{\circ} \mathrm{C}$. Surfactant $(50 \mu \mathrm{l}, 20 \mathrm{mg} / \mathrm{ml})$ was added when the broth turbidity reached $\mathrm{A}_{600}=0.2$. Bacterial cell growth was monitored by turbidity measurements at $600 \mathrm{~nm}$ at 1-hour intervals on a spectrophotometer (SPECTRO UV16 PC - MRC LAB). Aliquots of the cultures were taken at 2-hour intervals to assess for viability by plating and incubating at $37{ }^{\circ} \mathrm{C}$ for 24 hours, after which the presence of colonies was monitored. Samples were taken for microscopic examination 1 hour after the addition of each surfactant. Unstained samples were observed at 1000X magnification using an oil immersion lens on an inverted microscope (Inverted Laboratory Microscope Leica DM IL LED).

\subsection{Phospholipid binding studies.}

2.9.1. 1-Anilino-8-naphthalene sulfonate (ANS).

A mixture of aqueous surfactant solution $\left(1.00 \mathrm{ml}, 1 \times 10^{-3} \mathrm{M}\right)$ and DPPC in $0.01 \mathrm{M}$ Tris-buffered saline, $\mathrm{pH} 7.0\left(1.00 \mathrm{ml}, 2 \times 10^{-3} \mathrm{M}\right)$ was titrated with a stock solution of ANS. The fluorescence intensities $\left(\mathrm{F}_{\mathrm{b}}\right)$ after the addition of each $5 \mu \mathrm{L}$ of ANS solution were recorded at $480 \mathrm{~nm}$ (excited at $380 \mathrm{~nm}$ ). The slope of the linear plot was taken to be the emission coefficient of the ternary ANS complex $\left(\mathrm{A}_{\mathrm{t}}\right)$. The concentrations of the bound ANS, $\mathrm{X}_{\mathrm{b}}$, in these solutions, were calculated according to Equation 1.

$$
\mathrm{X}_{\mathrm{b}}=\left(\mathrm{F}_{\mathrm{b}}-\mathrm{F}_{0}\right) /\left(\mathrm{A}_{\mathrm{b}}-\mathrm{A}_{0}\right) \quad \text { Equation } 1
$$

$F_{b}$ and $F_{0}$ are the fluorescence intensities for solutions with and without lipid. $A_{b}$ and $A_{0}$ are the emission coefficients for lipid-bound and free ANS, respectively.

From the value of $X_{b}$, the concentrations of free and bound ANS were calculated for each solution, and the data were then treated using the Scatchard equation (Equation 2).

$$
\frac{v}{[P]}=n^{\prime} K-v K \quad \text { Equation } 2
$$

where $v$ is the number of moles of bound probe per mol of lipid, [P] is the free concentration of the probe, $\mathrm{n}^{\prime}$ is the maximum value of $v$, which indicates the binding capacity of the lipid for ANS; and $\mathrm{K}$ is the binding constant.

For the quantitative determination of the binding of ANS to lipid in the presence of the surfactant, a solution containing DPPC $\left(1.00 \mathrm{ml}, 4 \times 10^{-5} \mathrm{M}\right)$ and aqueous surfactant solution $\left(1.00 \mathrm{ml}, 10^{-3} \mathrm{M}\right)$ was titrated with a stock solution of ANS. The fluorescence intensity $\left(\mathrm{F}_{\mathrm{b}}\right)$ of each titration increment of $5 \mu \mathrm{l}$ was measured. The fluorescence intensities in the absence of DPPC $\left(\mathrm{F}_{0}\right)$ were obtained by measuring the fluorescence after the addition of each $5 \mu 1$ of ANS solution to a mixture of Tris buffer solution $(1.00 \mathrm{~mL}, 0.01 \mathrm{M})$ and surfactant $\left(1.00 \mathrm{ml}, 10^{-3} \mathrm{M}\right)$. The free and bound concentration of ANS corresponding to the ANS concentration added along the titration curve was calculated using $A_{t}$ in the same manner as described for the binary system. The binding parameters were determined using Equations 1 and 2.

\subsubsection{DPH (1,6-diphenyl-1,3,5-hexatriene).}

A stock solution of DPH in tetrahydrofuran $\left(10^{-4} \mathrm{M}\right)$ was freshly prepared and kept in the dark. Samples containing DPPC $\left(2.00 \mathrm{ml}, 1 \times 10^{-3} \mathrm{M}\right)$ with various concentrations of DPH 
$\left(5 \times 10^{-7} \mathrm{M}\right.$ to $\left.5 \times 10^{-6} \mathrm{M}\right)$ were incubated at $50^{\circ} \mathrm{C}$ for 1 hour and then cooled to room temperature after which the fluorescence intensities were measured. The experiment was again carried out using a lower concentration of DPPC solution $\left(2 \times 10^{-5} \mathrm{M}\right)$. The fraction of boundDPH in the solution of lower DPPC concentration was taken to be the ratio of its fluorescence with that of the solution containing $1 \times 10^{-3} \mathrm{M}$ DPPC at the same total concentration of DPH. The binding constant $\mathrm{K}$ and binding capacity $\mathrm{n}^{\prime}$ between DPH and DPPC vesicles were determined using Equation 2.

For the competitive binding studies, mixtures containing DPPC $\left(2.00 \mathrm{ml}, 2 \times 10^{-5} \mathrm{M}\right)$, and DPH $\left(5 \times 10^{-8} \mathrm{M}\right)$ were titrated against varying concentrations of the surfactant, and the fluorescence intensities after addition of each $5 \mu \mathrm{l}$ of surfactant solution were recorded as a function of the surfactant concentrations. The fraction of bound probe in the solution was taken to be the ratio of the fluorescence intensity obtained with that of the solution containing a higher concentration of DPPC $\left(1 \times 10^{-3} \mathrm{M}\right)$ and DPH $\left(5 \times 10^{-8} \mathrm{M}\right)$. The binding of the surfactants to DPPC was determined using Equation 3. This equation was derived from the competitive binding mechanism assuming that the surfactant competes for $\mathrm{n}^{\prime}{ }_{1}$ of the $\mathrm{n}^{\prime}$ probe binding sites with an intrinsic binding strength of $\mathrm{K}_{1}$.

$$
\frac{\left(\mathrm{n} \prime-v_{1}\right) v_{1}}{\left(\mathrm{n}^{\prime}-v^{*}-v_{1}\right)[\mathrm{D}]}=\mathrm{n}^{\prime}{ }_{1} \mathrm{~K}_{1}-v_{1} \mathrm{~K}_{1} \quad \text { Equation } 3
$$

where $v^{*}$ is the ratio of bound-probe per total lipid concentration in the presence of the surfactant; $v_{1}$ is the ratio of bound drug per total lipid concentration; $\mathrm{n}^{\prime}{ }_{1}$ is the maximum value of $v_{1}$, which indicates the probe binding sites which may be replaced by surfactant; [D] is the free surfactant concentration; $\mathrm{K}_{1}$ is the binding constant for the surfactant-lipid interaction; and $v_{1}$ was obtained from Equation 4, using $\mathrm{n}^{\prime}$ and $\mathrm{K}$ values from Equation 2.

$$
v_{1}=\mathrm{n}^{\prime}-v^{*}-\frac{v^{*}}{[\mathrm{P}]^{*} \mathrm{~K}} \quad \text { Equation } 4
$$

$[\mathrm{P}]^{*}$ represents the free concentration of the probe in the presence of the surfactants. [D] was taken to be the difference between the total concentration of the surfactant and the product of $v_{1}$ and total lipid concentration.

\subsection{Bovine Serum Albumin (BSA) binding properties.}

Fluorometric titration of a solution of BSA $(1 \mathrm{ml}, 10 \mu \mathrm{M})$ in $20 \mathrm{mM}$ phosphate buffer (pH 7.4), further diluted with phosphate buffer $(2 \mathrm{ml})$ with stock solutions of the methionine surfactants $(0.4 \mathrm{mM})$ was carried out. The solutions were excited at $295 \mathrm{~nm}$, and the intensity of the BSA solutions with and without surfactants was recorded at $336 \mathrm{~nm}$. In order to determine the thermodynamic parameters free energy $(\Delta \mathrm{G})$, enthalpy $(\Delta \mathrm{H})$, and entropy $(\Delta \mathrm{S})$, binding studies were carried out at 298, 308, and $313 \mathrm{~K}$.

\subsection{Molecular docking.}

The structures of the methionine derivatives, SURF1, SURF2, and QUAT3 were drawn and optimized using Avogadro 1.2.0 software and used as input for the docking calculations. The crystal structure of BSA was obtained from the Protein Data Bank (PDB, id: 4F5S), and hydrogen atoms were added using the Reduce package [21]. Gasteiger-Marsili charges [22] were then assigned to both the receptor and ligand atoms using Open Babel 2.3.90 [23] and imported into AutoDockTools. Docking was subsequently done using the Autodock 4.2 software [24]. A Lamarckian genetic algorithm (GA) was used to generate 100 low-energy conformations in which the flexible ligands were docked in the vicinity of Trp-213. Docking 
was done inside a three-dimensional grid box of size $(70 \times 70 \times 70) \AA$, with a grid spacing of $0.375 \AA$, centered on the Trp residue. Various different binding poses were found, and in order to generate comparable binding pockets for each surfactant, a large number of conformations had to be generated. In the interest of brevity, we only discuss in detail the docked conformations with the lowest free energy of binding in each case. Interaction diagrams were made with LigPlot+ [25].

\section{Results}

\subsection{Synthesis of surfactants.}

Several studies on the effect of chain length on antimicrobial activities of surfactants reported the dodecyl $\left(\mathrm{C}_{12}\right)$ derivative to show optimum activity as a result of an optimal hydrophobic-hydrophilic balance that enhanced interaction and penetration of the surfactant inside the membrane of the microorganisms [20]. Methionine and cystine derivatives containing one and two $\mathrm{C}_{12}$ hydrophobic chains, respectively, together with structural modification of the head group, were studied to investigate their effect on the physicochemical and biological properties of the sulfur-based system.

The free amine (SURF1), hydrochloride (SURF2), and quaternary ammonium derivatives (QUAT3) of the $\mathrm{C}_{12}$ methionine esters and the $\mathrm{C}_{12}$ Gemini cystine surfactant (GEM4) were synthesized (Figure 1). The synthesis and characterization of SURF1 and QUAT3 have been previously reported [19]. However, when similar reaction conditions were employed in the present work, low yields of the desired products SURF1 and QUAT3 were obtained, together with a significant amount of unreacted alcohol. When the reaction time was extended from 4 to 48 hours and purified using column chromatography, high-grade purity products were isolated.

The peak at $1733-1737 \mathrm{~cm}^{-1}$ in the IR spectra and $162.3-175.8 \mathrm{ppm}$ in the ${ }^{13} \mathrm{C}$ NMR spectra confirmed the formation of ester linkage in the surfactants. A downfield shift of 0.5 ppm in the signal of the hydrogen attached to the alpha carbon confirmed the formation of the hydrochloride salt, SURF2. The presence of the singlet at $\delta 3.55 \mathrm{ppm}(9 \mathrm{H})$ corresponding to 3 methyl groups confirmed the formation of the QUAT 3. The structure of GEM4 was confirmed using 2-D NMR spectroscopy. Selected data are represented in Table 1.

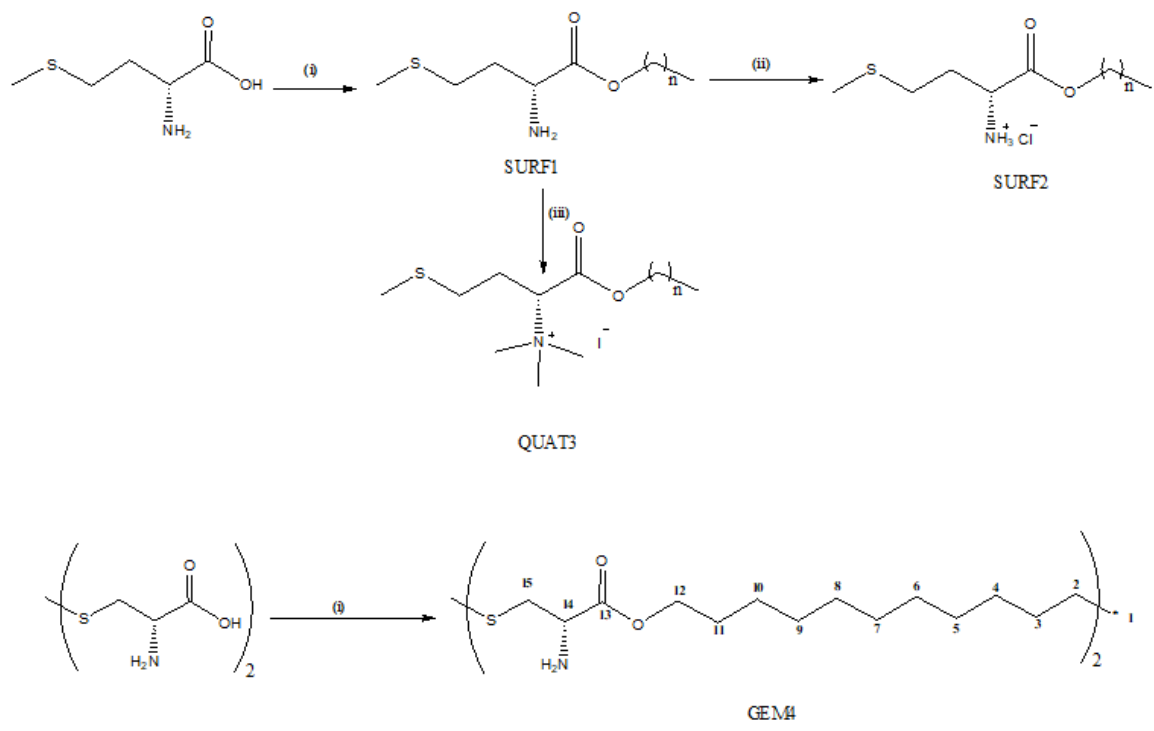

Figure 1. Synthesis of surfactants. (i) 1-dodecanol, PTSA, refluxing toluene 24 hours; (ii) HCl; (iii) MeI, $\mathrm{K}_{2} \mathrm{CO}_{3}$, acetonitrile, r.t, 24 hours. 
Table 1. Selected NMR assignment of GEM4.

\begin{tabular}{|c|c|c|c|c|c|}
\hline Assignment & $\begin{array}{l}{ }^{1} \mathrm{H}-\mathrm{NMR} \\
\delta / \mathrm{ppm}\end{array}$ & $\begin{array}{c}{ }^{13} \mathrm{C}-\mathrm{NMR} \\
\delta / \mathrm{ppm}\end{array}$ & DEPT NMR & COSY & НМВС \\
\hline 1 & $0.77-0.82$ & 14.1 & $-\mathrm{CH}_{3}$ & 2 & $\mathrm{H}_{2}, \mathrm{H}_{3}$ \\
\hline 2 & \multirow{4}{*}{$1.18-1.22$} & 22.7 & $-\mathrm{CH}_{2}$ & 1 & $\mathrm{H}_{1}, \mathrm{H}_{4}$ \\
\hline 3 & & 31.9 & $-\mathrm{CH}_{2}$ & 2,4 & $\mathrm{H}_{1}, \mathrm{H}_{5}$ \\
\hline $4-9$ & & $29.2-29.6$ & $-\mathrm{CH}_{2}$ & & $\mathrm{H}_{2}, \mathrm{H}_{6}$ \\
\hline 10 & & $25.8-25.9$ & $-\mathrm{CH}_{2}$ & & $\mathrm{H}_{8}, \mathrm{H}_{11}, \mathrm{H}_{12}$ \\
\hline 11 & $1.54-1.62$ & 28.5 & $-\mathrm{CH}_{2}$ & 10,12 & $\mathrm{H}_{9}, \mathrm{H}_{12}$ \\
\hline 12 & $4.03-4.08$ & 65.6 & $-\mathrm{CH}_{2}$ & 11 & $\mathrm{H}_{10}, \mathrm{H}_{11}$ \\
\hline 13 & - & 173.7 & - & & $\mathrm{H}_{15}, \mathrm{H}_{14}$ \\
\hline 14 & $3.69-3.82$ & 53.6 & $-\mathrm{CH}$ & 15 & $\mathrm{H}_{15}$ \\
\hline 15 & $2.79-3.09$ & 43.6 & $-\mathrm{CH}_{2}$ & 14 & $\mathrm{H}_{14}$ \\
\hline
\end{tabular}

\subsection{Antibacterial activity tests.}

3.2.1. Minimum inhibitory concentration.

The synthesized non-ionic (SURF1, GEM4) and cationic (SURF2, QUAT3) containing $\mathrm{C}_{12}$-alkyl chain surfactants were screened against a range of Gram-positive and Gram-negative test bacteria. The antibacterial activity was expressed as MIC, which gives a quantitative assessment of the tested compounds and represents the lowest concentration that inhibits visible bacterial growth (Table 2). All surfactants displayed moderate to high antibacterial activities against the bacteria tested. Amongst the four surfactants, QUAT3 showed the highest activity against both Gram-positive and Gram-negative bacteria.

Table 2. Minimum inhibitory concentration and critical micellar concentrations of sulfur-based amino acid surfactants.

\begin{tabular}{|c|c|c|c|c|c|c|}
\hline \multirow{2}{*}{\multicolumn{2}{|c|}{ Test organisms }} & \multicolumn{5}{|c|}{$\mathrm{MIC}(\mathrm{mM})$} \\
\hline & & \multirow{2}{*}{$\begin{array}{c}\text { SURF1 } \\
0.984\end{array}$} & \multirow{2}{*}{$\begin{array}{c}\text { SURF2 } \\
3.53\end{array}$} & \multirow{2}{*}{$\begin{array}{c}\text { QUAT3 } \\
0.080\end{array}$} & \multirow{2}{*}{$\begin{array}{c}\text { GEM4 } \\
2.18\end{array}$} & \multirow{2}{*}{$\begin{array}{c}\text { Tetracycline } \\
11.25\end{array}$} \\
\hline Gram-positive & Staphylococcus epidermidis (ATCC 12228) & & & & & \\
\hline bacteria & Bacillus cereus (ATCC 11778) & 0.01 & 0.001 & 0.002 & 4.33 & 0.005 \\
\hline & Staphylococcus aureus (ATCC 29213) & 0.13 & 0.03 & 0.01 & 4.33 & 0.005 \\
\hline \multirow{3}{*}{$\begin{array}{l}\text { Gram-negative } \\
\text { bacteria }\end{array}$} & Escherichia coli (ATCC 25922) & 2.46 & 2.21 & 0.04 & 4.33 & 0.005 \\
\hline & Klebsiella pneumoniae (ATCC 13883) & 8.34 & 0.441 & 0.004 & 0.04 & 0.011 \\
\hline & Pseudomonas aeruginosa (ATCC 27853) & 8.34 & 3.53 & 0.03 & 2.18 & 1.41 \\
\hline $\mathbf{C M C} / \mathbf{m M}$ & & $0.25 *$ & $2.19 * *$ & $0.68 * *$ & $0.041 *$ & \\
\hline
\end{tabular}

3.2.2. Broth macrodilution assay.

Based on the MIC values obtained, we examined the effect of QUAT3 on the growth of $K$. pneumoniae and B. cereus and of GEM4 on the growth of $K$. pneumoniae using the broth macro-dilution assay. Bacterial growth curves show the relationship between the cell population, as measured by turbidity versus time. Following the start of the exponential phase $\left(\mathrm{A}_{600}=0.2\right)$ and the addition of QUAT3 and GEM4 to K. pneumoniae, a decrease in absorbance was observed compared to the negative control (Figure 2a). A similar effect was observed on B. cereus upon the addition of QUAT3 (Figure 2b). QUAT3 and/or GEM4 showed comparable effects as the positive control tetracycline (Figure 2). Aliquots of each culture were taken at two-hourly intervals to assess cell viability. Cells were found to be viable up to 6-hrs after the addition of surfactants. At $\mathrm{t}=8$ hours, no colonies were observed. 

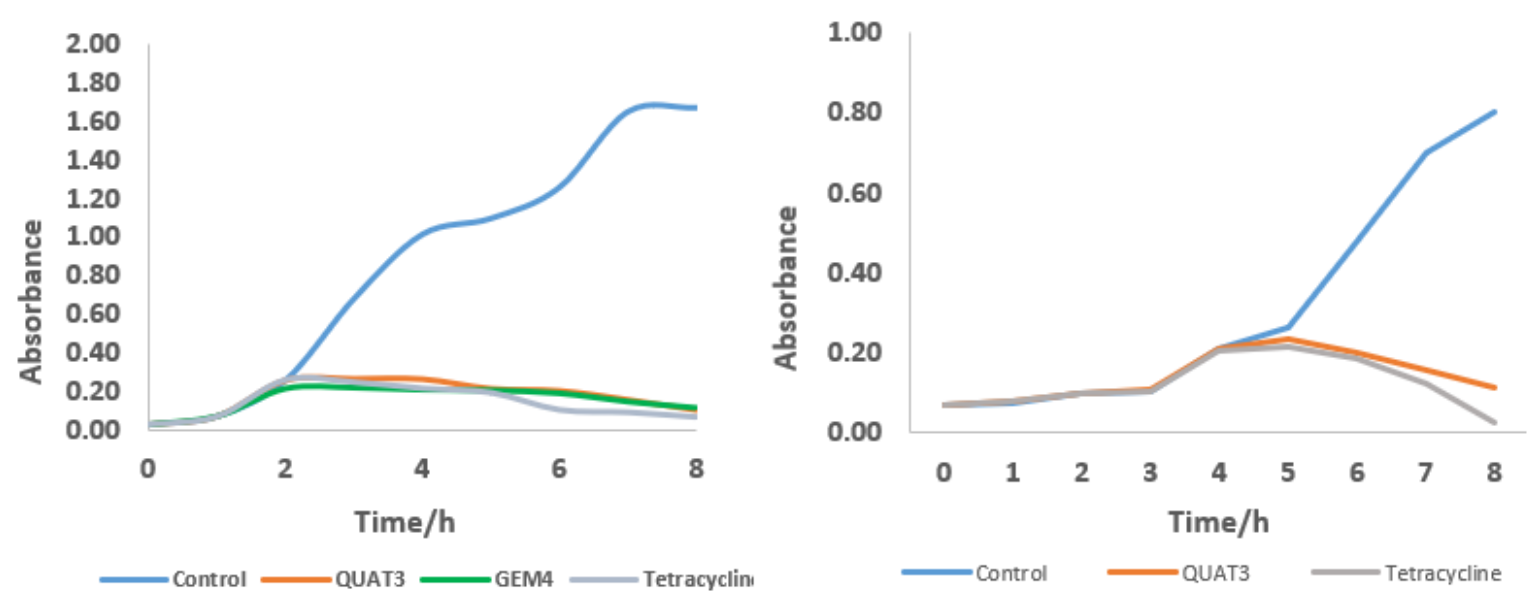

Figure 2. Effect of QUAT3 and GEM4 on bacterial growth. (a) Klebsiella pneumoniae; (b) Bacillus cereus. Bacterial population growth was monitored by measuring the absorbance at $600 \mathrm{~nm}$. Surfactants were added at $\mathrm{A} 600=0.2$.

The effect of cationic QUAT3 and GEM4 on bacterial cell integrity was evaluated against the Gram-negative K. pneumoniae and the Gram-positive B. cereus. Cells from the control culture of $K$. pneumoniae appeared to be of high density and agglomerated to each other, generating a thick layer of biofilm. After 1 hour of incubation with QUAT3 and GEM4, fewer cells were observed, and the cells no longer agglomerated. However, cells treated with QUAT3 retained their rod shape, whereas those with GEM4 assumed pleiomorphic forms, indicative of cell wall disruption (Figure 3). The addition of QUAT3 to B. cereus disrupted the chains and shape of the rod cells (Figure 4).

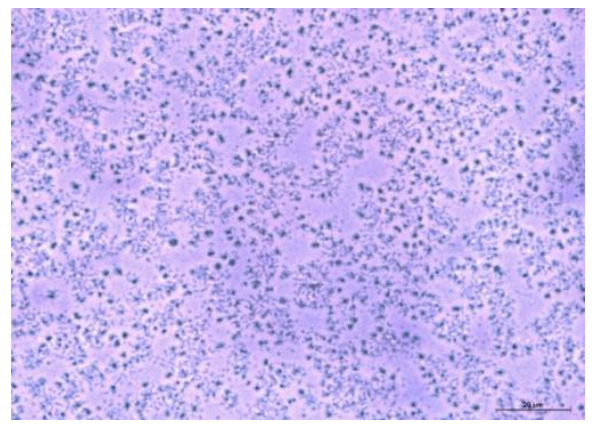

(a)

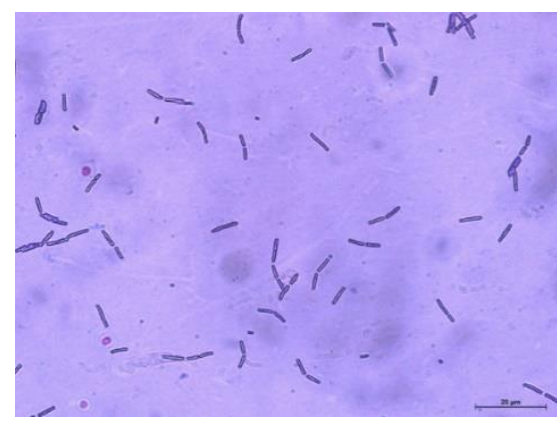

(b)

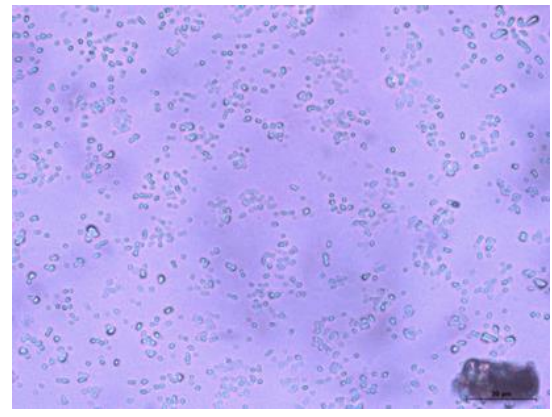

(c)

Figure 3. Effect of QUAT3 and GEM4 on K. pneumoniae bacterial integrity. (a) Control without surfactant; (b) QUAT3; (c) GEM4. Samples were examined microscopically (1000X) after 1 hour of incubation with each surfactant. 


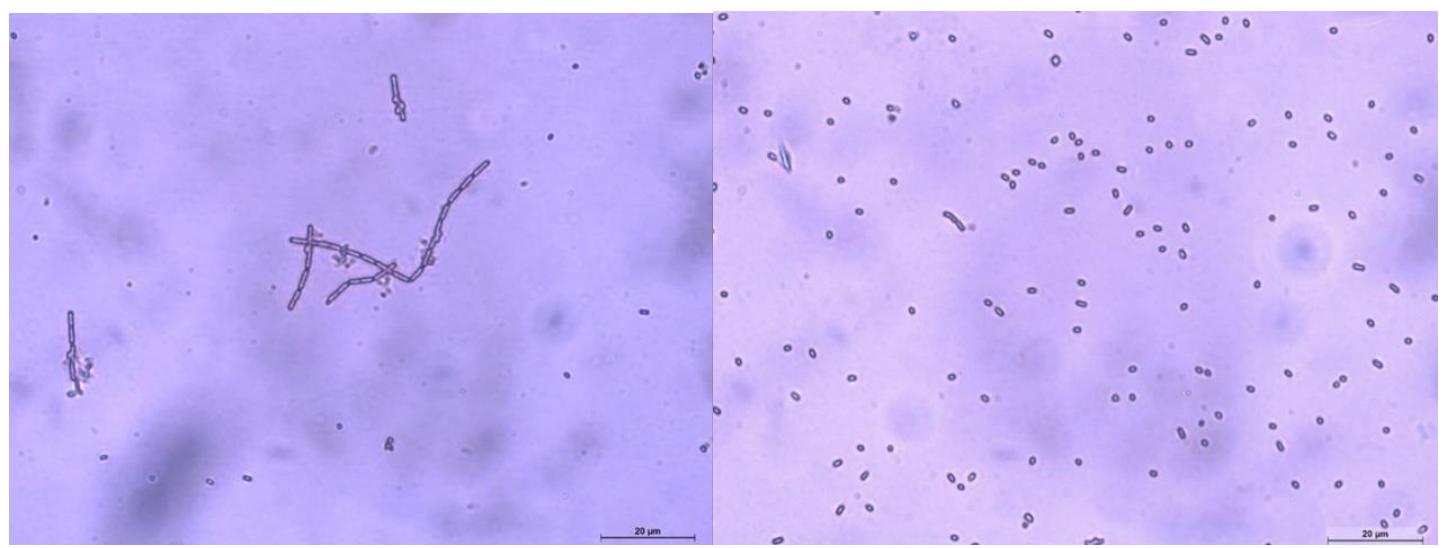

Figure 4. Effect of QUAT 3 on B. cereus bacterial structure. (a) No surfactant; (b) QUAT3. Samples were examined microscopically (1000X) after $1 \mathrm{hr}$ of incubation with each surfactant.

\subsection{Phospholipid binding studies.}

The phospholipid 1,2-dipalmitoyl-sn-glycero-3-phosphocholine (DPPC) is a simple membrane model used to probe the mechanism of action of small molecules with bacterial membranes [26-28].

The influence of the head groups (free amine or cationic) and additional hydrophobic chains in GEM4 on the binding abilities with phospholipid DPPC were investigated in the presence of the fluorescence probes 1-anilino-8-naphthalenesulfonate (ANS) and 1,6-diphenyl1,3,5-hexatriene (DPH). The emission coefficient of free ANS, $\mathrm{A}_{0}$, and lipid-bound, ANSDPPC, $A_{b}$ was $1 \times 10^{7}$ and $5 \times 10^{8}$, respectively [20]. The fluorescence intensity of the ANSDPPC system increased upon the addition of SURF1, SURF2, and QUAT3, respectively, indicating the higher binding of fluorophores to the binary system, in the order of QUAT3 > SURF2 > SURF1 (Figure 5). GEM4, containing the cystine moiety, showed a lower fluorescence enhancement compared to the methionine derivatives.

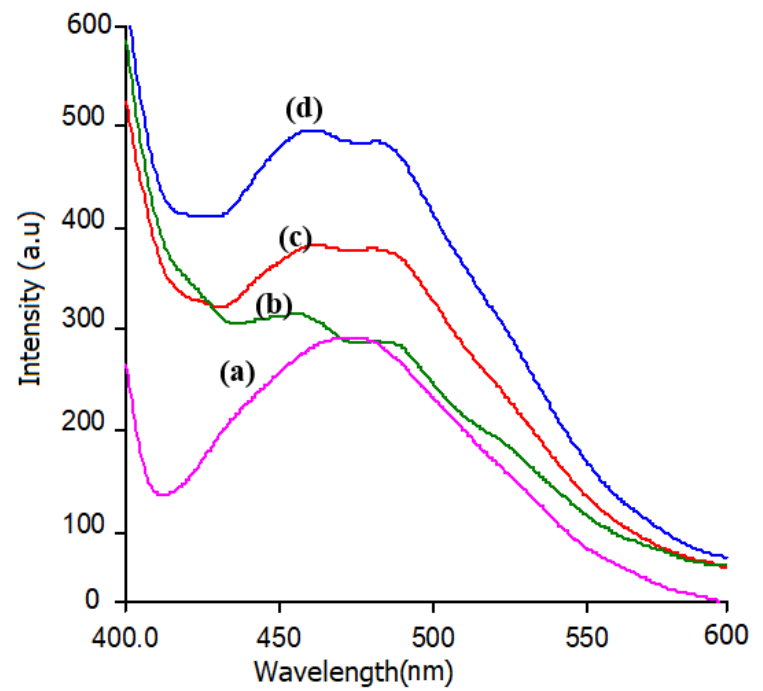

Figure 5. Fluorescence intensity spectra of solutions containing $1.22 \times 10^{-7} \mathrm{M}$ ANS and $1 \times 10^{-3} \mathrm{M}$ DPPC in the presence and absence of methionine derivatives.

The increase in the binding constants $(\mathrm{K})$ in the presence of the surfactants suggests that the surfactants induced a secondary binding between the probe and the lipid (Table 3). The cationic species SURF2 and QUAT3 showed greater binding ability with DPPC than the free amine derivatives SURF1 and GEM4. Surfactants binding with DPPC via hydrophobic 
interactions will compete with DPH in the binary DPH-DPPC, causing a decrease in the binding constant, $\mathrm{K}_{1}$ and binding site $\mathrm{n}^{\prime} \mathbf{1}$.

Table 3. Binding constants of ANS and DPH to DPPC in the presence of surfactants.

\begin{tabular}{c|c|c|c|c} 
& \multicolumn{2}{|c}{ ANS probe } & \multicolumn{2}{c}{ DPH probe } \\
\hline Surfactants & $\mathrm{K}\left(\mathrm{M}^{-1}\right)$ & $\mathrm{n}^{\prime}$ & $\mathrm{K}_{1}\left(\mathrm{M}^{-1}\right)$ & $\mathrm{n}^{\prime}{ }_{1}$ \\
\hline SURF1 & $1 \times 10^{7}$ & 0.00175 & $1.12 \times 10^{4}$ & 0.010 \\
\hline SURF2 & $3 \times 10^{7}$ & 0.00704 & $2.72 \times 10^{4}$ & 0.017 \\
\hline QUAT3 & $5 \times 10^{7}$ & 0.00497 & $5.70 \times 10^{3}$ & 0.008 \\
\hline GEM4 & $6 \times 10^{6}$ & 0.00278 & $3.24 \times 10^{5}$ & 0.0287 \\
\hline CTAB & $6 \times 10^{7}$ & 0.00080 & $1.48 \times 10^{5}$ & 0.014 \\
\hline Streptomycin $^{\text {Control }}{ }^{1 *}$ & $9 \times 10^{6}$ & 0.00190 & $3.00 \times 10^{6}$ & 0.015 \\
\hline & $2 \times 10^{6}$ & 0.00163 & $3.00 \times 10^{6}$ & 0.032
\end{tabular}

All surfactants were found to decrease the fluorescence intensity of the lipid-DPH solution, indicating a binding displacement of DPH by the surfactants, which bind in close proximity to the DPH binding site. Figure 6 shows the effect of QUAT3 on the lipid-DPH system.

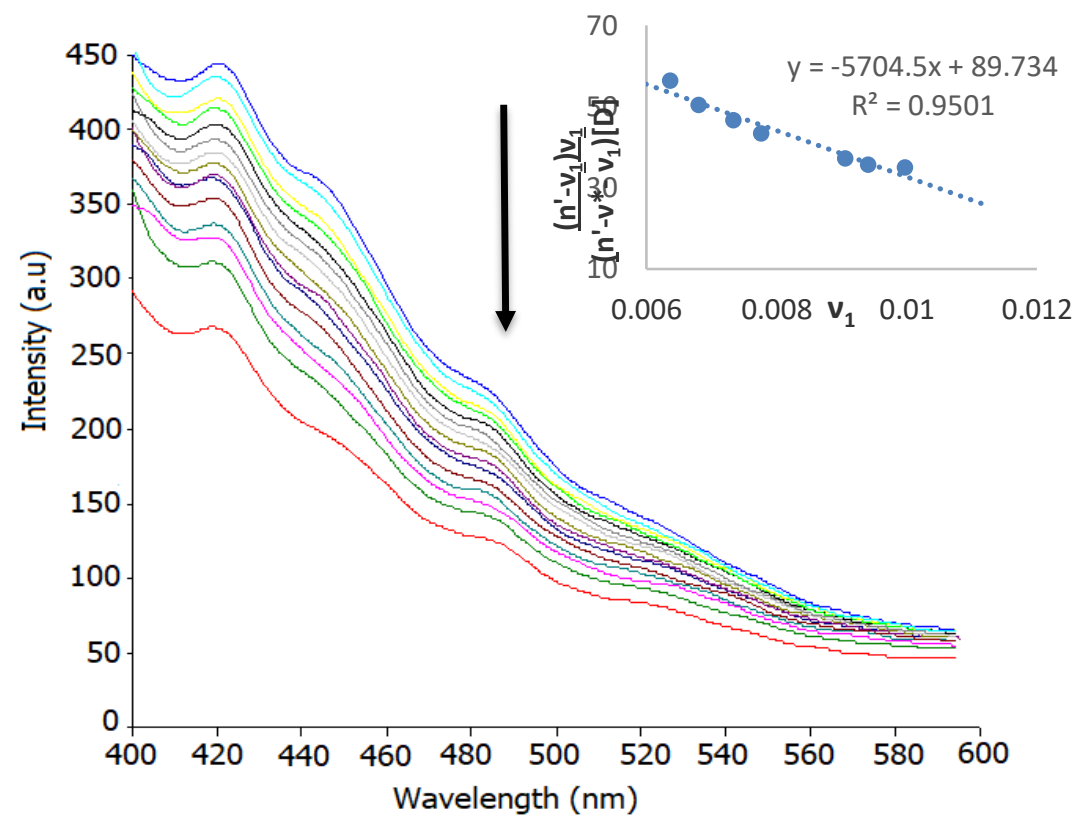

Figure 6. Effect of concentration of QUAT3 on the fluorescence intensity of DPPC-DPH.

The $\mathrm{K}_{1}$ and n' 1 values were much lower in the presence of the surfactants, implying that the surfactants competed for the DPH binding sites by providing greater hydrophobic interaction with the lipid. The compounds were found to interact with DPPC by hydrophobic interaction in the order of QUAT3 > SURF2> SURF1> GEM4 (Table 3).

\subsection{Bovine serum albumin (BSA) binding studies.}

Albumin in blood plasma helps bind and transport many endogenous and exogenous compounds in the body [29].

\subsubsection{Fluorescence spectroscopy.}

To understand the potential mode of distribution of the surfactants (SURF1, SURF2, QUAT3 and GEM4) in blood plasma, their interaction with bovine serum albumin (BSA) was investigated using fluorescence spectroscopy. This technique has been widely used in many 
studies to monitor the conformation changes, dynamics, and intermolecular interactions between BSA and surfactant molecules. A decrease in fluorescence intensity of BSA, together with a slight blue shift, was observed upon the addition of each surfactant, indicating proteinsurfactant interaction (Figure 7).

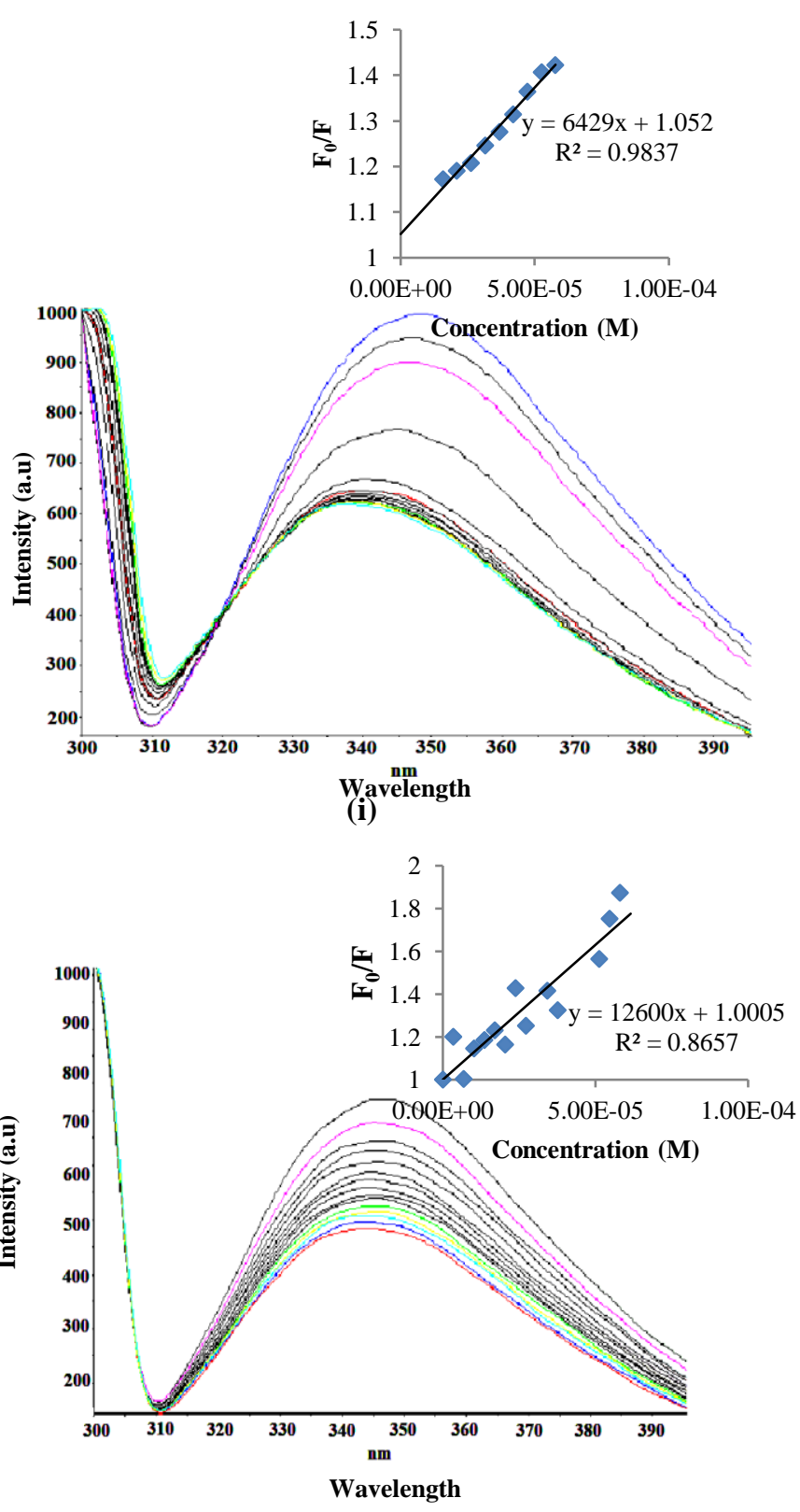

(iii)

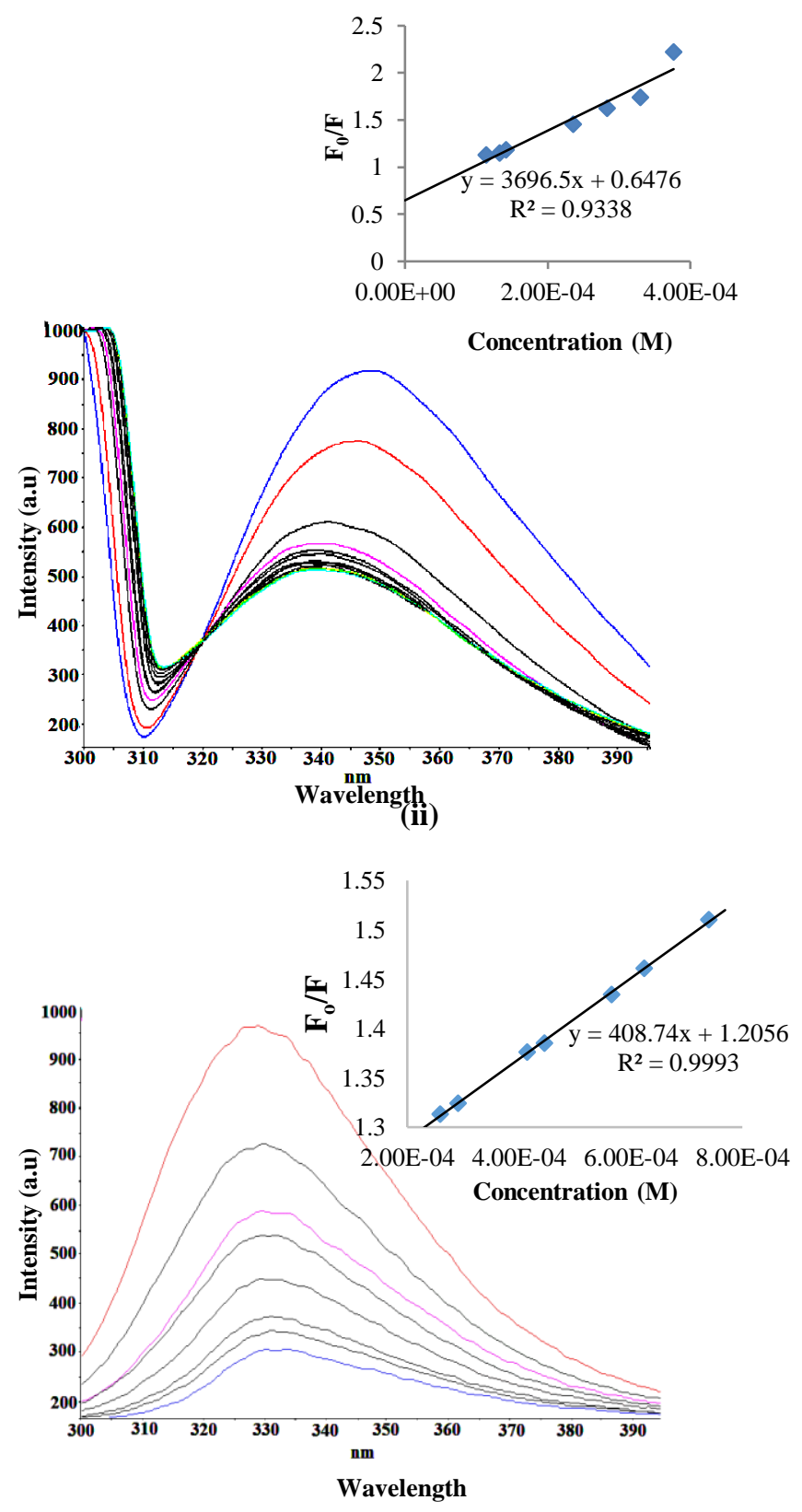

(iv)

Figure 7. Fluorescence spectra and Stern-Volmer plots of the binding of (i) SURF1 (ii) SURF2, (iii) QUAT3, and (iv) GEM4

The Stern-Volmer equation (Equation 5) was used to determine the mode of quenching. Albumin present in blood plasma helps bind and transport many endogenous and exogenous compounds in the body [30]. To understand the potential mode of distribution of the surfactants (SURF1, SURF2, QUAT3 and GEM4) in blood plasma, their interaction with bovine serum albumin (BSA) was investigated.

$$
\mathrm{F}_{\mathrm{O}} / \mathrm{F}=\mathrm{K}_{\mathrm{SV}}[\mathrm{Q}]+1=\mathrm{k}_{\mathrm{q}} \tau 0[\mathrm{Q}]+1 \quad \text { Equation } 5
$$

$F_{0}$ and $F$ : the fluorescence intensities in the absence and in the presence of the compounds, respectively. 
[Q]: equilibrium concentration of the quencher (surfactants).

$\mathrm{K}_{\text {Sv }}$ : the binding constant

$\mathrm{k}_{\mathrm{q}}$ : apparent bimolecular quenching rate constant

$\tau 0$ : average lifetime of the biomolecule without the quencher and its value is $10^{-8} \mathrm{~s}$.

The Stern-Volmer constants $\left(\mathrm{K}_{\mathrm{Sv}}\right)$ were determined from the plot of $F_{0} / F$ versus surfactants concentration (Figure 7 and Table 4).

Table 4. The Stern-Volmer quenching constant $\left(\mathrm{K}_{\mathrm{Sv}}\right)$, bimolecular quenching constant $\left(\mathrm{k}_{\mathrm{q}}\right)$, the apparent binding constant $\left(\mathrm{K}_{\mathrm{a}}\right)$ and the number of binding sites, $n$ of the surfactants with BSA.

\begin{tabular}{c|l|l|l|c} 
Surfactants & $\mathbf{K}_{\mathbf{S v}},(\mathbf{m m o l} / \mathbf{l})$ & $\mathbf{K}_{\mathbf{q}}\left(\times \mathbf{1 0}^{\mathbf{1 1}}\right)$ & $\mathbf{K}_{\mathbf{a}}\left(\mathbf{M}^{-\mathbf{1}}\right)$ & $\boldsymbol{n}$ \\
\hline SURF1 & $6.43 \times 10^{3}$ & 6.43 & $1.60 \times 10^{3}$ & 0.84 \\
SURF2 & $3.70 \times 10^{3}$ & 3.70 & $1.35 \times 10^{4}$ & 1.23 \\
QUAT3 & $1.26 \times 10^{4}$ & 12.6 & $3.92 \times 10^{5}$ & 1.35 \\
\hline GEM4 & $4.08 \times 10^{2}$ & 0.41 & $0.0136 \times 10^{3}$ & 0.46
\end{tabular}

The calculated $\mathrm{k}_{\mathrm{q}}$ was larger than the maximum scattering collision quenching rate constant $\left(2 \times 10^{10} \mathrm{M}^{-1} \mathrm{~s}^{-1}\right.$ in dynamic quenching), which indicated that the quenching of BSA with the surfactants followed a static process [30] rather than a dynamic one.

The apparent binding constant $\left(\mathrm{K}_{\mathrm{a}}\right)$ and the number of binding sites $(n)$ were calculated using the double reciprocal plot (Equation 6 and Figure 8).

$$
\log \left(F_{0}-F\right) / F=\log K_{\mathrm{a}}+n \log [Q]
$$

Equation 6

QUAT3 showed the highest binding strength with BSA, followed by SURF2 and SURF1, while GEM4 showed a very low binding constant value (Table 4).

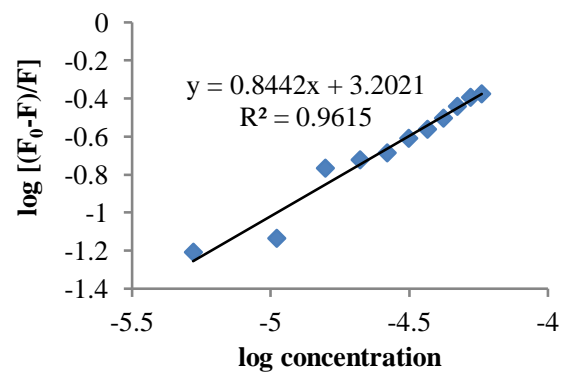

(i)

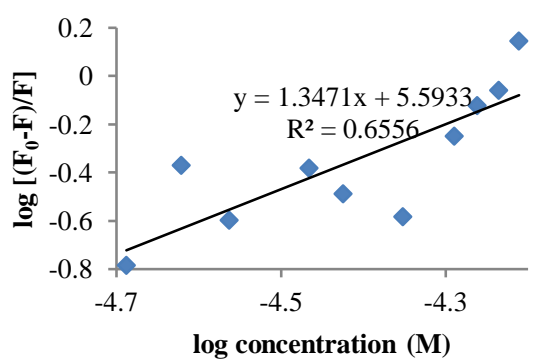

(iii)

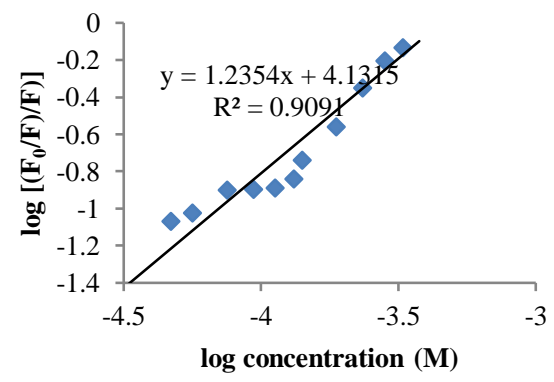

(ii)

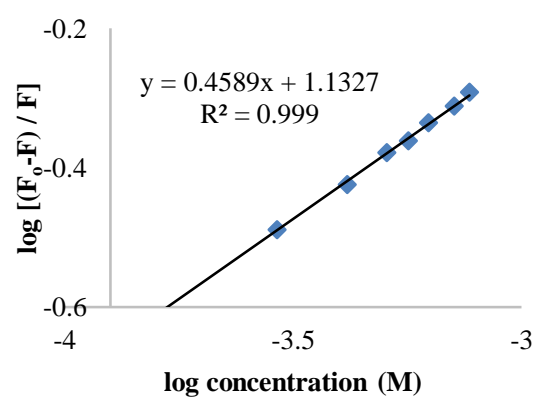

(iv)

Figure 8. Double logarithmic plots of the binding of (i) SURF1; (ii) SURF2; (iii) QUAT3; (iv) GEM4 with BSA.

\subsubsection{Thermodynamics of binding.}

The thermodynamic parameters were determined at 298, 308, and $313 \mathrm{~K}$ (Figure 9). The values of free energy $(\Delta G)$ were calculated from Equations 7 and 9 . The values of $\Delta H$ and $\Delta \mathrm{S}$ can be analyzed based on the van't Hoff's formula (Equation 8 ). 


$$
\begin{array}{cr}
\Delta \mathrm{G}=-\mathrm{RT} \ln \mathrm{K}_{\mathrm{a}} & \text { Equation 7 } \\
\ln k_{a}=-\frac{\Delta H}{R T}+\frac{\Delta S}{R} & \text { Equation 8 } \\
\Delta \mathrm{G}=\Delta \mathrm{H}-\mathrm{T} \Delta \mathrm{S} & \text { Equation 9 }
\end{array}
$$

T: absolute temperature

$\mathrm{K}_{\mathrm{a}}$ : the binding constant at temperature $\mathrm{T}$

$\mathrm{R}$ : gas constant

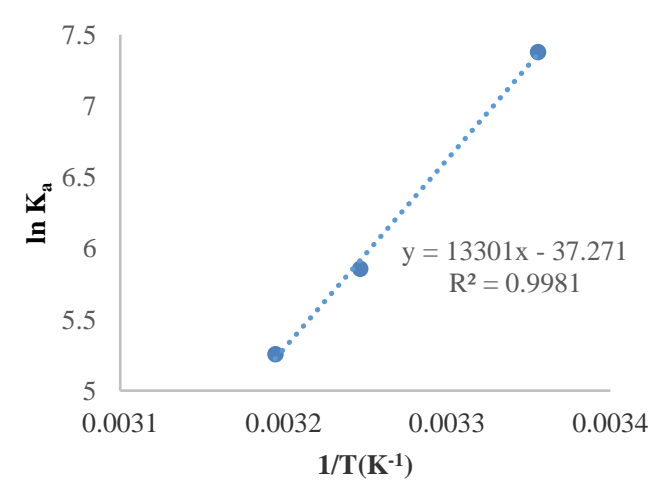

(i)

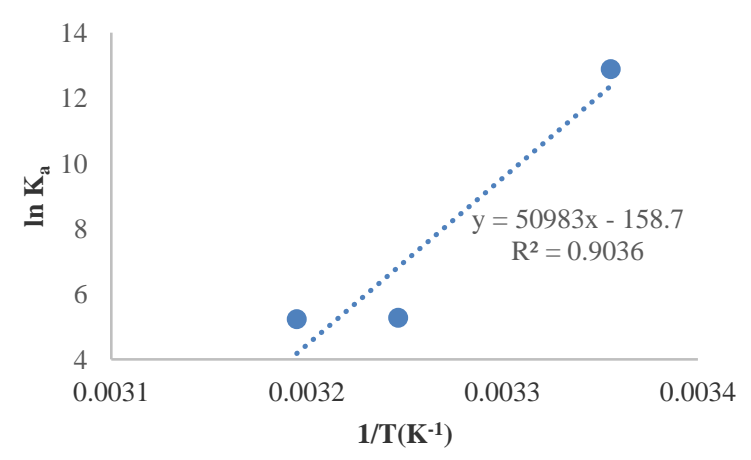

(iii)

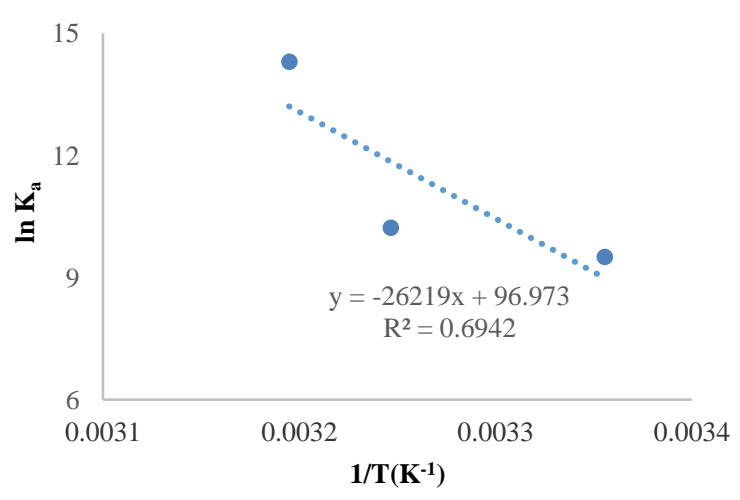

(ii)

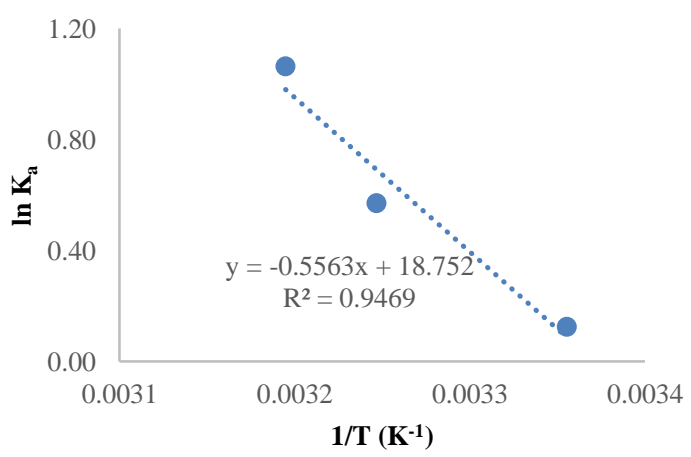

(iv)

Figure 9. Van't Hoff plots for the surfactants/BSA system. (i) SURF1; (ii) SURF2; (iii) QUAT3; (iv) GEM4.

SURF1 and QUAT3 showed negative $\Delta H$ and $\Delta \mathrm{S}$ values (Table 5), indicating that the binding of these surfactants with BSA occurs mainly via van der Waals' forces and hydrogen

\begin{tabular}{|c|c|c|c|c|c|c|c|}
\hline Surfactant & $\begin{array}{c}\text { Temperature } \\
(\mathbf{K})\end{array}$ & $n$ & $K_{a}\left(M^{-1}\right)$ & $\ln K_{\mathbf{a}}$ & $\begin{array}{c}\Delta \mathrm{G} \\
\left(\mathbf{k J m o l} \mathbf{l}^{-1}\right)\end{array}$ & $\begin{array}{c}\Delta \mathbf{H}^{\circ} \\
\left(\mathbf{k J m o l}{ }^{-1}\right)\end{array}$ & $\begin{array}{c}\Delta \mathrm{S}^{\circ} \\
\left(\mathrm{Jk}^{1} \mathrm{~mol}^{-1}\right)\end{array}$ \\
\hline \multirow{3}{*}{ SURF1 } & 298 & 0.84 & $1.60 \times 10^{3}$ & 7.38 & -18.28 & \multirow{3}{*}{-110.5} & \multirow{3}{*}{-309.72} \\
\hline & 308 & 1.23 & $3.48 \times 10^{2}$ & 5.86 & -15.00 & & \\
\hline & 313 & 1.35 & $1.92 \times 10^{2}$ & 5.26 & -13.68 & & \\
\hline \multirow{3}{*}{ SURF2 } & 298 & 0.67 & $1.35 \times 10^{4}$ & 9.51 & -23.55 & \multirow{3}{*}{217.88} & \multirow{3}{*}{805.85} \\
\hline & 308 & 1.12 & $2.76 \times 10^{4}$ & 10.23 & -26.18 & & \\
\hline & 313 & 0.58 & $1.62 \times 10^{6}$ & 14.30 & -37.19 & & \\
\hline QUAT3 & 298 & 0.56 & $3.92 \times 10^{5}$ & 12.88 & -31.90 & -423.67 & -1318.8 \\
\hline
\end{tabular}
bonding. Positive values of $\Delta \mathrm{H}$ and $\Delta \mathrm{S}$ were obtained for SURF2, showing that hydrophobic interactions are more prominent [31]. The binding constant obtained for GEM4 is very low, with negative and positive values for $\Delta \mathrm{H}$ and $\Delta \mathrm{S}$, respectively, therefore no conclusions could be drawn.

Table 5. Thermodynamic parameters of BSA-surfactant interaction in phosphate buffer. 


\begin{tabular}{|c|c|c|c|c|c|c|c|}
\hline Surfactant & $\begin{array}{c}\text { Temperature } \\
\text { (K) }\end{array}$ & $n$ & $\mathbf{K}_{\mathbf{a}}\left(\mathbf{M}^{-1}\right)$ & $\ln K_{\mathbf{a}}$ & $\underset{(\mathbf{k J m o l}}{\Delta \mathbf{G})}$ & $\begin{array}{c}\Delta \mathbf{H}^{\circ} \\
\left(\mathrm{kJmol}^{-1}\right)\end{array}$ & $\begin{array}{c}\Delta \mathrm{S}^{\circ} \\
\left(\mathrm{Jk}-{ }^{1} \mathrm{~mol}^{-1}\right)\end{array}$ \\
\hline & 308 & 1.85 & $1.97 \times 10^{2}$ & 5.28 & -13.51 & & \\
\hline & 313 & 0.63 & $1.87 \times 10^{2}$ & 5.23 & -13.60 & & \\
\hline \multirow{3}{*}{ GEM4 } & 298 & 0.46 & $1.36 \times 10^{-2}$ & 0.12 & -92.71 & \multirow{3}{*}{-46.25} & \multirow{3}{*}{155.90} \\
\hline & 308 & 0.65 & $5.84 \times 10^{-2}$ & 0.57 & -94.27 & & \\
\hline & 313 & 0.95 & $7.83 \times 10^{-1}$ & 1.06 & -95.04 & & \\
\hline
\end{tabular}

3.4.3. Molecular Docking Studies.

In order to confirm the mode of action of the binding of surfactants with BSA, molecular docking studies were undertaken. Molecular docking of GEM4 was not feasible because it exceeds the number of torsions that can be run on the software as AutoDock is normally used to work with small drug-like molecules (limited to 12 torsion angles) [24,25].

The negative $\Delta \mathrm{G}$ values indicated the interaction between the methionine derivatives (SURF1, SURF2, and QUAT3) and BSA to be spontaneous (Table 6). The interaction of the surfactants with BSA was found to be in the order of QUAT3 > SURF2 > SURF1 which was similar to the trend observed in fluorescence binding studies.

The binding pocket was further analyzed to investigate the different residues of BSA to which the surfactants are interacting (Figure 10).

Table 6. The binding ability of methionine surfactants to BSA.

\begin{tabular}{c|c} 
Compound & $\boldsymbol{\Delta} \mathbf{G}_{\text {bind }} \mathbf{k J} / \mathbf{m o l}$ \\
\hline SURF1 & -16.26 \\
\hline SURF2 & -19.40 \\
\hline QUAT3 & -19.86
\end{tabular}

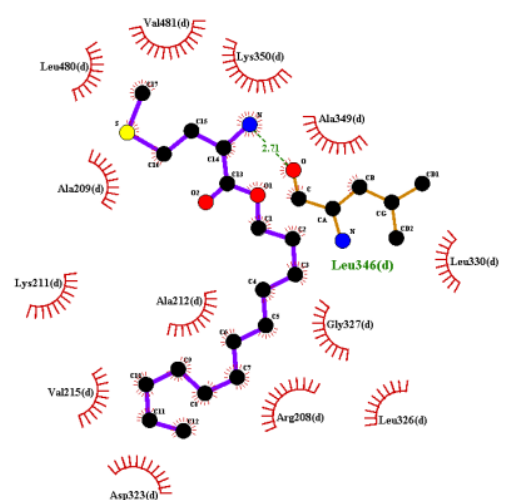

(a)

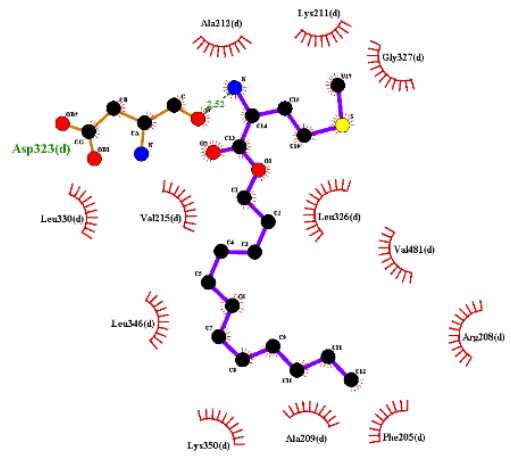

(b)

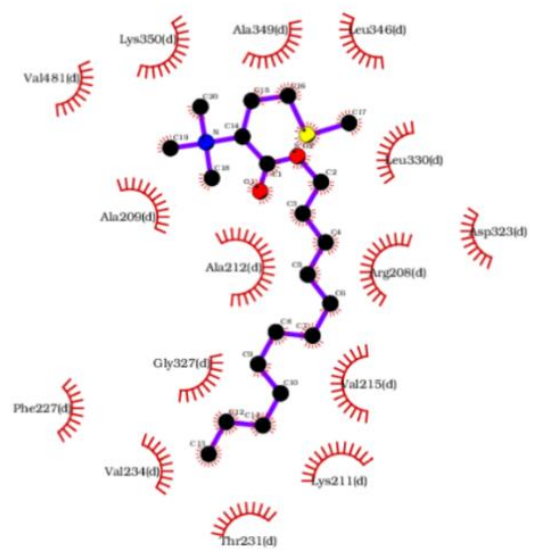

(c)

Figure 9. Interaction diagrams for docking of (a) SURF1; (b) SURF2; (c) QUAT3 in the vicinity of Trp-213 of BSA. 
Molecular docking showed that QUAT3 shared hydrophobic interactions with more amino acid residues than SURF1 or SURF2 in the binding site of BSA. The amino group of SURF1 and SURF2 was found to hydrogen bond with the carboxylic moiety of Leu-346 and Asp-323, respectively (Table 7), while QUAT3 interacted with 15 amino acid residues via hydrophobic interactions.

Table 7. Amino acid residues of BSA show hydrogen bonding and hydrophobic interactions with SURF1, SURF2, and QUAT3.

\begin{tabular}{c|c|c} 
Surfactant & $\begin{array}{c}\text { Residues showing H- } \\
\text { bonding interactions }\end{array}$ & $\begin{array}{c}\text { Residues showing hydrophobic interaction residues } \\
\text { SURF1 }\end{array}$ \\
& Leu-346 & $\begin{array}{c}\text { Leu-480, Val-481, Lys-350, Ala-349, Leu-330, Gly-327, Arg-208, Leu-326, } \\
\text { Asp-323, Val-215, Ala-212, Lys-211, Ala-209 }\end{array}$ \\
\hline SURF2 & Asp-323 & $\begin{array}{c}\text { Ala-212, Lys-211, Gly-327, Leu-326, Val-481, Arg-208, Phe-205, Ala-209, } \\
\text { Lys-350, Leu-346, Val-215, Leu-330 }\end{array}$ \\
\hline QUAT3 & - & $\begin{array}{r}\text { Val-481, Lys-350, Ala-349, Leu-346, Leu-330, Arg-208, Asp-323, Val-215, } \\
\text { Lys-211, Thr-231, Val-234, Gly-327, Phen-227, Ala-212, Ala-209 }\end{array}$
\end{tabular}

\section{Discussion}

This study synthesized sulfur-based $\mathrm{C}_{12}$ monoalkyl methionine (SURF1, SURF2, QUAT3), and the $\mathrm{C}_{12}$ Gemini cystine (GEM4) surfactants displayed antibacterial activities.

The presence of a cationic head group was found to affect the micellisation of the surfactants (Table 1). The higher CMC values of SURF2 and QUAT3 are due to increased electrostatic repulsion forces between the positively charged head groups, making micelle formation less favorable than non-ionic SURF1 [12]. The lower CMC of QUAT3 compared to SURF2 is due to the presence of three methyl groups, which screen the electrostatic head-group repulsion and provide additional hydrophobic interactions between the surfactant's head group and facilitate surfactant self-assembly [20,32]. The presence of two hydrophobic chains favors micelle formation through hydrophobic interactions, resulting in lower CMC in GEM 4.

An antimicrobial agent can interact with bacteria through various targets such as the cell wall, cytoplasmic membrane and/or the cytoplasm. Surfactant molecules have the ability to destabilize bacterial membranes by incorporating them into the bilayer, leading to cell lysis. The overall negative surface charge on their membrane generally renders bacteria more susceptible to positively-charged molecules. Cationic surfactants interact with the bacterial membrane through electrostatic forces between the surfactants' head group and the negatively charged membrane, followed by hydrophobic interaction between the surfactants' tail and the hydrophobic portion the membrane bilayer. This explains the relatively higher antibacterial activity of the SURF2 and QUAT3, which bear a positive charge on their head group, enhancing their antibacterial potential. The better antibacterial activity of QUAT3 may be due to the presence of three methyl groups on the amino moiety $\left(-\mathrm{N}^{+}\left(\mathrm{CH}_{3}\right)_{3}\right)$, which allowed better interaction between the surfactant and the bacterial cell membrane through additional hydrophobic interactions with the phospholipids [33,34]. Gram-negative bacteria have a complex membrane structure consisting of a thin peptidoglycan inner layer together with an outer membrane covered with lipopolysaccharide (LPS), whereas Gram-positive bacteria have a thick multi-layered peptidoglycan layer with no outer membrane. For a compound to behave as an antibacterial agent towards Gram-negative bacteria, it first has to penetrate the outer membrane in order to reach its target. SURF2, QUAT3, and GEM4 were found to be active towards $K$. pneumoniae, likely due to the presence of the disulfide linkage and the lipophilic $\mathrm{C}_{12}$ chain. Gemini surfactants bearing two hydrophobic chains can provide additional 
hydrophobic interactions, which aid in the lysis of bacterial membranes. Apart from $K$. pneumoniae, GEM4 showed relatively poor activity against the other test pathogens. We can infer from growth curve patterns and cell viability assays that both QUAT3 and GEM4 inhibit cell division and appear to act as bacteriostatic agents rather than cell lysis bactericidal agents.

The presence of a cationic head group favors the binding of the surfactants to the negatively charged phospholipid via electrostatic interactions, giving rise to an overall positive charge on the surfactant-DPPC complex, hence creating a more conducive condition for the binding of ANS. The methyl groups in QUAT3 contribute to additional hydrophobic interactions with the phospholipid, causing a greater quenching of the lipid-bound DPH. GEM4, despite having two hydrophobic chains, showed lower binding ability, which could be due to the large size of the molecule that hampers its diffusion across the phospholipid layer. The trend for the binding ability explains the antibacterial activities, showing that electrostatic interactions play a major role in the lysis of the bacterial membrane. The absence of a positive charge, the large molecular size of GEM4, and the high tendency to form micelles may collectively be responsible for the relatively low antibacterial activities and lower interactions with the phospholipids.

Due to its net negative charge, BSA tends to interact with cationic species via electrostatic interactions [35,36]. Compounds can also bind with BSA through hydrogen bonding and van der Waals' forces through hydrophobic interactions. Tryptophan residues, namely Trp213 and Trp135, have been reported to be a prominent fluorescent signature to determine the interaction between a compound and BSA. The decrease in fluorescent intensity and the blue shift reflects changes in the microenvironment in and around the Trp residues upon adding surfactants. However, although the surfactants were able to bind in the vicinity of Trp residues, molecular docking did not show direct interactions between the surfactants and the Trp residues. QUAT3 showed hydrophobic interactions with more amino acid residues than SURF1 and SURF2 within the binding site of BSA. The additional hydrophobic interactions with BSA help stabilize the BSA/surfactant complex, thus increasing binding efficiency. QUAT3 showed higher $K_{a}$ values, indicating that it had a better plasmatic distribution compared to other surfactants [29]. From the thermodynamic parameters of enthalpy and entropy, it can be deduced that the modes of binding of SURF1 and QUAT3 occur mainly via van der Waals' forces and hydrogen bonding. At the same time, in the case of SURF2, hydrophobic interactions are more prominent. Molecular docking studies in the vicinity of the Trp residues showed that SURF1 and SURF2 interact with BSA via hydrogen bonding and hydrophobic interactions, while QUAT3 was found to interact with BSA mainly via hydrophobic interactions.

\section{Conclusions}

The synthesis of two cationic and two neutral sulfur-based amino acid-based surfactants is economically viable, and they are readily biodegradable by virtue of their design. In particular, the cationic surfactant QUAT3 showed excellent antibacterial activity due to the hydrophobic and lipophilic balance in its structure and its net positive charge density. The demonstrated biological properties of QUAT3 open new avenues for developing a potent class of antibacterial agents. 


\section{Funding}

This research was funded by the Higher Education Commission, Mauritius, grant number INT2018-14.

\section{Acknowledgments}

The authors would like to express their appreciation for the technical support to Ms. Neelofur Jaunnoo and Ms. Darshinee Cadervaloo.

\section{Conflicts of Interest}

\section{The authors declare no conflict of interest.}

\section{References}

1. Guoying, W.; Zhao, G.; Chao, X.; Xie, L.; Hongju, W. The characteristic of virulence, biofilm and antibiotic resistance of Klebsiella pneumonia. International Journal of Environmental Research and Public Health 2020, 17, 1-17, https://doi.org/10.3390/ijerph17176278.

2. Obłąk, E.; Piecuch, A.; Rewak-Soroczyńska, J.;Paluch, E. Activity of gemini quaternary ammonium salts against microorganisms. Applied Microbiology And Biotechnology 2019, 103, 625-632, https://doi.org/10.1007/s00253-018-9523-2.

3. Falk, N.A. Surfactants as antimicrobials: A brief overview of microbial interfacial chemistry and surfactant antimicrobial activity. Journal of Surfactants And Detergents 2019, 22, 1119-1127, https://doi.org/10.1002/jsde.12293.

4. Sharma, P.; Parthasarathi, S.; Patil, N.; Waskar, M.; Raut, J.; Puranik, M.; Ayappa, K.; Basu, J. Assessing barriers for antimicrobial penetration in complex asymmetric bacterial membranes: A case study with thymol. Langmuir 2020, 36, 8800-8814, https://doi.org/10.1021/acs.langmuir.0c01124.

5. Zhou, C.; Wang, Y. Structure-activity relationship of cationic surfactants as antimicrobial agents. Current Opinion in Colloid \& Interface Science 2020, 45, 28-43, https://doi.org/10.1016/j.cocis.2019.11.009.

6. Mba, I.; Nweze, E. Nanoparticles as therapeutic options for treating multidrug-resistant bacteria: research progress, challenges, and prospects. World Journal of Microbiology and Biotechnology 2021, 37, 1-30, https://doi.org/10.1007/s11274-021-03070-X.

7. Pérez, L.; Pinazo, A.; Moran, M.; Pons, R. Aggregation behavior, antibacterial activity and biocompatibility of catanionic assemblies based on amino acid-derived surfactants. International Journal of Molecular Sciences 2020, 21, 1-30. https://doi.org/10.3390/ijms21238912.

8. Joondan, N.; Jhaumeer Laulloo, S.; Caumul, P. Amino acids: Building blocks for the synthesis of greener amphiphiles. Journal Of Dispersion Science And Technology 2018, 39, 1550-1564, https://doi.org/10.1080/01932691.2017.1421085.

9. Roy, S.; Das, P.K. Antibacterial hydrogels of amino acid-based cationic amphiphiles. Biotechnology And Bioengineering 2008, 100, 756-764, https://doi.org/10.1002/bit.21803.

10. Kopiasz, R.; Rukasz, A.; Chreptowicz, K.; Podgórski, R.; Kuzminska, A.; Mierzejewska, J.; Tomaszewski, W.; Ciach, T.; Janczewski, D. Influence of lipid bilayer composition on the activity of antimicrobial quaternary ammonium ionenes, the interplay of intrinsic lipid curvature and polymer hydrophobicity, the role of cardiolipin. Colloids and Surfaces B: Biointerfaces 2021, 207, 1-13, https://doi.org/10.1016/j.colsurfb.2021.112016.

11. Joondan, N.; Inassee, M.; Bhowon, M.; Jhaumeer Laulloo, S. Synthesis and biological properties of a series of aryl alkyl disulfide derivatives. Heliyon 2020, 6, e05368, https://doi.org/10.1016/j.heliyon.2020.e05368.

12. Pinazo, A.; Manresa, M.A.; Marques, A.M.; Bustelo, M.; Espuny, M.J.; Pérez, L. Amino acid-based surfactants: New antimicrobial agents. Advances In Colloid And Interface Science 2016, 228, 17-39, https://doi.org/10.1016/j.cis.2015.11.007.

13. Kaczerewska, O.; Sousa, I.; Martins, R.; Figuieredo, J.; Loureiro, S.; Tedim, J. Gemini surfactant as a template agent for the synthesis of more eco-friendly silica nanocapsules. Applied Sciences 2020, 10, 1-13, https://doi.org/10.3390/app10228085. 
14. Joondan, N.; Radhan, A.; Jhaumeer Laulloo, S.; Caumul, P. Synthesis and physicochemical properties of nonionic and cationic. Synthetic Organic Chemistry, 2017, https://sciforum.net/manuscripts/4800/manuscript.pdf.

15. Taseidifar, M. Environmental applications of a biodegradable cysteine-based surfactant. Ecotoxicology and Environmental Safety 2020, 206, 1-6. https://doi.org/10.1016/j.ecoenv.2020.111389.

16. Wang, N.; Yao, K.; Wang, Y.; Ti, J.; Tan, J.; Liu, C.; Zhang, G.; Wang, C.; Xu, B. Green synthesis, characterization, and properties of acyl lysine, serine, threonine, and methionine derived from three types of natural oils. Journal of Surfactants and Detergents 2020, 23, 239-250, https://doi.org/10.1002/jsde.12365.

17. Kyung, K.H.; Lee, Y.C. Antimicrobial activities of sulfur compounds derived froms-alk (en) yl-l-cysteine sulfoxides in allium and brassica. Food Reviews International 2001, 17, 183-198, https://doi.org/10.1081/fri100000268.

18. Yoshimura, T.; Sakato, A.; Tsuchiya, K.; Ohkubo, T.; Sakai, H.; Abe, M.; Esumi, K. Adsorption and aggregation properties of amino acid-based $\mathrm{N}$-alkyl cysteine monomeric and -dialkyl cystine gemini surfactants. Journal of Colloid And Interface Science 2007, 308, 466-473, https://doi:10.1016/j.jcis.2006.11.038.

19. Perinelli, D.R.; Petrelli, D.; Vitali, L.A.; Vllasaliu, D.; Cespi, M.; Giorgioni, G.; Elmowafy, E.; Bonacucina, G.; Palmieri, G.F. Quaternary ammonium surfactants derived from leucine and methionine: Novel challenging surface active molecules with antimicrobial activity. Journal of Molecular Liquids 2019, 283, 249-256, https://doi.org/10.1016/j.molliq.2019.03.083.

20. Joondan, N.; Jhaumeer Laulloo, S.; Caumul, P. A study of the antibacterial activity of L-phenylalanine and L-tyrosine esters in relation to their CMCs and their interactions with 1,2-dipalmitoyl-sn-glycero-3phosphocholine, DPPC as model membrane. Microbiological Research 2014, 169, 675-685, https://doi.org/10.1016/j.micres.2014.02.010.

21. 21.Word, J.M.; Lovell, S.C.; Richardson, J.S.; Richardson, D.C. Asparagine and glutamine : using hydrogen atom contacts in the choice of side-chain amide orientation. Journal of Molecular Biology 1999, 285, 17351747, https://doi.org/10.1006/jmbi.1998.2401.

22. Gasteiger, J.; Marsili, M. A new model for calculating atomic charges in molecules. Tetrahedron Letters 1978, 34, 3181-3184. https://doi.org/10.1016/S0040-4039(01)94977-9.

23. O'Boyle, N.M.; Banck, M.; James, C.A.; Morley, C.; Vandermeersch, T.; Hutchison, G.R.; OpenBabel : An open chemical toolbox. Journal of Cheminformatics 2011, 33, 1-14, https://doi.org/10.1186/1758-2946-3-33.

24. Laskowski, R.A.; Swindells, M.B. LigPlot+: Multiple ligand-protein interaction diagrams for drug discovery. Journal Chemical Information Modeling 2011, 51, 2778-2786, https://doi.org/10.1021/ci200227u.

25. Morris, G.M.; Huey, R.; Lindstrom, W.; Sanner, M.F.; Belew, R.K.; Goodsell, D.S.; Olson, A.J. AutoDock 4 and autodocktools4: Automated docking with selective receptor flexibility. Journal of Computational Chemistry 2009, 30, 2785-2791, https://doi.org/10.1002/jcc.21256.

26. Lozano, N.; Perez, L.; Pons, R.; Luque-Ortega, J.R.; Fernandez-Reyes, M.; Rivas, L.; Pinazo, A. Interaction studies of diacyl glycerol arginine-based surfactants with DPPC and DMPC monolayers, relation with antimicrobial activity. Colloids and Surfaces A: Physicochemical and Engineering Aspects 2008, 319, 196203, https://doi.org/10.1016/j.colsurfa.2007.07.015.

27. Andrade, S.; Ramalho, M.; Loureiro, J.; Pereira, M. Liposomes as biomembrane models: Biophysical techniques for drug membrane interaction studies. Journal of Molecular Liquids 2021, 334, 1-16, https:/doi.org/10.1016/j.molliq.2021.116141.

28. Drescher, S.; Van Hoogevest, P. The phospholipid research center: Current research in phospholipids and their use in drug delivery. Pharmaceutics 2020, 12, 1-36, https://doi.org/10.3390/pharmaceutics12121235.

29. Spada, A.; Emami, J.; Tuszynski, J.; Lavasanifar, A. The uniqueness of Albumin as a carrier in nanodrug $\begin{array}{lllll}\text { delivery. } & \text { Molecular } & \text { Pharmaceutics } & \mathbf{2 0 2 1}, & 18,\end{array}$ https://doi.org/10.1021/acs.molpharmaceut.1c00046.

30. Valstar, A.; Almgren, M.; Brown, W.; Vasilescu, M. The interaction of bovine serum albumin with surfactants studied by light scattering. Langmuir 2000, 16, 922-927, https://doi.org/10.1021/la990423i.

31. Teng, Y.; Liu, R.; Yan, S.; Pan, X.; Zhang, P.; Wang, M. Spectroscopic investigation on the toxicological interactions of 4-aminoantipyrine with bovine hemoglobin. Journal of Fluorescence 2010, 20, 381-387, https://doi.org/10.1007/s10895-009-0543-2.

32. Joondan, N.; Jhaumeer Laulloo, S.; Caumul, P.; Akerman, M. Synthesis, physicochemical, and biological activities of novel $\mathrm{N}$-acyl tyrosine monomeric and gemini surfactants in single and SDS/CTAB-mixed micellar system. Journal of Physical Organic Chemistry 2016, 30, e3675, https://doi.org/10.1002/poc.3675. 
33. Freitas, E.; Moura Jr, C.; Kerwald, J.; Beppu, M. An overview of current knowledge on the properties, synthesis and applications of quaternary chitosan derivatives. Polymers 2020, 12, 1-41, https://doi.org/10.3390/polym12122878.

34. Phan, H.M.; Bartelt-Hunt, S.; Rodenhausen, K.B.; Schubert, M.; Bartz, J.C. Investigation of Bovine Serum Albumin (BSA) attachment onto Self-Assembled Monolayers (SAMs) using combinatorial Quartz Crystal Microbalance with Dissipation (QCM-D) and Spectroscopic Ellipsometry (SE). PLOS ONE 2015, 10, e0141282, https://doi.org/10.1371/journal.pone.0141282.

35. Rusu, A.; Chiriac, A.; Nita, L.; Rosca, I.; Rusu, D.; Neamtu, I. Self-assembled nanocarriers based on modified chitosan for biomedical applications: Preparation and characterization. Polymers 2020, 12, 1-18, https://doi.org/103390/polym12112593.

36. Aguilera-Garrido, A.; Castillo-Santaella, T.; Yang, Y.; Galisteo-González, F.; Gálvez-Ruiz, M.; MolinaBolivar, J.; Holgado-Terriza, J.; Cabrerizo-Vilchez, M.; Maldonado-Valderrama, J. Applications of serum albumins in delivery systems: Differences in interfacial behavior and interacting abilities with polysaccharides. Advances in Colloid and Interface Science 2021, 1-16, https://doi.org/10.1016/j.cis.2021.102365. 